Jenny Hufenreuter1', Josephine Otto1, Michael Linden*

\title{
Quality Assurance in Psychiatric Occupational Therapy by Treatment Manuals: Patients' Perceptions of Resistance- and Regeneration-specific Occupational Therapy.
}

\author{
${ }^{1}$ Research Group Psychosomatic Rehabilitation, Charité University Medicine Berlin, Berlin, Germany \\ *email: michael.lindendacharite.de
}

DOI: $10.2478 / g p-2018-0010$

Received: 1 August 2018; Accepted: 22 September 2018

\begin{abstract}
Objectives: Training, treatment and quality assurance in occupational therapy need guidelines and manuals. Two manuals and corresponding manual adherence checklists were developed for resistance- and regeneration-oriented treatment strategies, which are standard in occupational therapy. The hypothesis is that occupational therapists can apply different treatments and that this can be measured.

Methods: In a psychiatric-psychosomatic rehabilitation hospital, 108 patients were randomly assigned to the regeneration group and 113 to the resistance group. Patients were asked to indicate on a manual adherence checklist which interventions they had experienced during treatment. Additionally, a convenience sample of 124 patients who had not participated in the special groups but only in routine occupational therapy was interviewed at the end of the hospital stay.

Results: Resistance-oriented interventions were significantly more often reported in the resistance group and regeneration-oriented intervention was reported in the regeneration group.

Conclusions: The study demonstrates that the occupational therapy can be standardised according to treatment manuals and that protocol adherence can be ascertained, similar to that in other psychotherapies. This is important for training, practice, research and quality control, as manual guided and monitored treatment allows transparency in regard to what should and what has been done in therapy.
\end{abstract}

\section{Keywords}

Quality assurance, manualised occupational therapy, protocol adherence, quality control, standardisation

\section{INTRODUCTION}

Occupational therapy or ergotherapy has a wide spectrum of treatment goals, such as training of occupational skills, teaching social competencies, supporting activation, relaxation, and well-being or caring for patients in hospitals while they wait for other treatments. There is a wide range of therapeutic interventions (DRV, 2012; DVE, 1995; Hillert et al., 2009; Jerosch-Herold et al., 1999; Linden, 2013; Presber, 2003; WFOT, 2010). What exactly is or should be done in occupational therapy depends on the setting, the type of patients and most of all on individual experiences and preferences of the occupational therapists. Regarding psychiatric patients, there are some studies on the effects of occupational therapy in gerontology (Dooley \& Hinojosa, 2004; Graff et al., 2008, Hogan et al., 2004; Lawton, 1997), pediatrics and prevention (Barlow \& Parsons, 2003; Foxcroft et al., 2003; Neil \& Christensen, 2007; Waddel et al., 2007), or neurology (Barclay-Goddard et al., 2011), depression
(Blackwell et al., 2012 ) or unselected patient groups (Bryant et al., 2014; Buchain et al., 2003; Reuster 2006). Because of the many facettes of occupational therapy, it is difficult to standardise treatment procedures, so that there is a lack of specified therapeutic concepts and a need of controlled clinical studies (Steultjens et al., 2005). Scientific evidence and standardisation of procedures is of importance for teaching and training of occupational therapists, for guiding treatment and for quality assurance (Myers \& Lotz, 2017; Szucs et al., 2017; Zarafonitis et al., 2014).

The objective of the present study has been to develop treatment manuals and methods for quality assurance in occupational therapy, to allow therapists to follow evidencebased procedures. We chose two different treatment modes, resistance- and regeneration-oriented treatments. These are standard procedures in occupational therapy for patients with mental disorders. In the resistance-oriented treatment, patients are supported to learn how to overcome difficulties 
and hardiness by learning endurance and resilience. In the regeneration-oriented treatment, the goal is to help patients recover and get back their strengths. Additionally, we wanted to develop an instrument that allows to assess protocol adherence.

\section{MATERIALS AND METHODS}

\section{Patients}

The study was performed in a department of behavioural and psychosomatic rehabilitation (Dept. of Behavioral and Psychosomatic Medicine at the Rehabilitation Center Seehof of the Federal German Pension Fund, Teltow/Berlin, Germany). All patients were routinely treated with about $6 \mathrm{~h}$ of occupational therapy per week; individual psychotherapy, sports therapy or social therapy was added to the medical treatment. They were asked whether they would participate in a special seminar on stress management. After giving their informed consent, they were either allocated to the regeneration or the recreation group.

There were three study group sessions per week, each lasting $90 \mathrm{~min}$. The average treatment duration was 5 weeks, so participation in sessions on all topics was possible. Treatment was given by specially trained therapists and supervised by the head occupational therapist $(\mathrm{JH})$ and the study coordinator, a clinical psychologist and behaviour therapist (JO). During the study period of 12 months, 972 patients were admitted as inpatients, 231 were interested in participating in the additional treatment offer and 10 dropped out before the first session. A total of 108 patients were assigned to the regeneration group and 29 dropped out during the treatment. A total of 113 patients were assigned to the resistance group and 33 dropped out early. Complete data were available for 70 patients in the regeneration group and 75 patients in the resistance group.

Additionally, a convenience sample of 124 who had not participated in the special groups but only in routine occupational therapy (treatment as usual, TAU) patients was interviewed at the end of the hospital stay.

Patients were, on an average, 50.8 (s.d. 9.7) years old; $62.6 \%$ were female, $27.9 \%$ had a high school or university education and $53.5 \%$ were married. About $55.2 \%$ of the patients were in a full-time job, $18.9 \%$ were in a part-time job and $23.9 \%$ were unemployed. Primary clinical diagnoses were affective disorders (F30-F39:43.4\%), anxiety and somatoform disorders (F40-F49: 33.2\%) and personality disorders (F60-F69: 11.5\%). There were no significant differences between groups.

\section{Manuals and group contents}

Regeneration-oriented occupational therapy has a hedonic and salutotherapeutic focus (Linden \& Weig, 2009) and wants to help the patients to relax, to distract oneself from the burdens of life and also to recover. Treatment interventions include engaging in positive activities, hobbies, self-care or mindful indulgence (Fava \& Tomba, 2009; Lutz, 2008). Resistance-oriented therapy has the goal to promote endurance, hardiness, coping with stressors, readiness and motivation to work. Interventions are to confront patients with work-related tasks or specific hardiness training with reframing after successful tasks (Kobasa, 1979). According to these different approaches, the two treatment manuals were written. On the basis of discussions with occupational therapists, interventions that were used in their routine were collected. These were grouped in regeneration-oriented and in resistance-oriented activities. There were 5 thematic blocks and 15 technical recommendations per treatment, which are listed in Table 1. Occupational therapists were instructed to adhere to the manuals as good as possible. They were already well experienced in the individual methods and techniques that were requested.

Therapists in both the groups were encouraged to have a supportive and warm relationship with the patients. At the beginning of each session, they had to greet patients and then inform them about the 'topic of the day', that is, which treatment block was the goal of this session. This was supported by short written information with daily topics such as 'If you feel bad, then take care of yourself' or 'If you feel bad, just go on'. These were specific for the treatment of this particular session and for the different treatments. Then patients were asked to work, for example, on soapstone and train according to the topic of the day either to withstand adversity or to relax and distract.

\section{Assessment of protocol adherence}

There are many instruments to measure protocol adherence in psychotherapy (Flückiger et al., 2015; Horvath \& Greenberg, 1986; Höger \& Eckert, 1997; Linden \& Langhoff, 2010; Pohl et al., 2000; Staats et al., 2003). We referred to the Behavior Therapist Competency Checklist (BTCC; Linden et al., 2007, Linden \& Langhoff 2010), which can be adjusted to different treatments. The technical concept of the BTCC is to give characteristic samples of the treatment. Patients or therapists are then asked whether a respective activity has occurred during treatment. Table 2 lists the items that cover resistance and regeneration items, such as 'I was trained to enhance my 
Table 1. Therapeutic interventions in the regeneration and the resistance group

\begin{tabular}{|c|c|}
\hline Resistance group & Regeneration group \\
\hline Frustration training (origami) & Recreational activities (collection and planning of hobbies and activities) \\
\hline Endurance training (soap stone) & $\begin{array}{c}\text { Ability to relish and hedonic rules (eating, tea ceremony, mindfulness } \\
\text { cooking) }\end{array}$ \\
\hline Accuracy training (silhouette cuttings, basketry) & $\begin{array}{l}\text { Self-care and relaxation (wax bath, relaxation and imagination exercises, } \\
\text { mindfulness walks) }\end{array}$ \\
\hline $\begin{array}{l}\text { Goal orientation and acceptance of undesired tasks } \\
\text { (working with hard wood) }\end{array}$ & First impression formation (clothing, hairstyle, situational adjustment) \\
\hline $\begin{array}{c}\text { Acceptance of stress and criticism lenkaustik, } \\
\text { aquarelle painting, soap stone with swapping with the } \\
\text { neighbour during working on the task) }\end{array}$ & Interaction and small talk (parlour games, small talk) \\
\hline
\end{tabular}

level of stamina in dealing with tasks' as an example of resistance training or 'I had nice and relaxing conversations with the other patients' as an example for regeneration fostering. Patients have been asked to indicate on a seven-point Likert scale whether this specific intervention has been done (I agree: 1 $=$ not at all; $2=$ hardly; $3=$ a little, $4=$ somewhat; $5=$ largely; 6 = definitely; 7 = completely). Whatever the therapists may have done, what the patients have experienced is important. Such ratings of therapeutic interventions are an economic and a valid way for quality assurance in evidence-based medicine (Willutzki et al., 2013). Analyses of variance and multiple $\mathrm{t}$-tests were used to compare means of the treatment groups.

\section{Ethical considerations}

The study groups were added to the routine care; so that the patients not only got everything they would have received during the regular treatment but even more treatment. The type of treatment in the special groups is part of any occupational therapy so that no special risks for patients are to be expected.

Patients were asked to give their written consent after they had been informed about the study by the occupational therapists and by written information.

The study was approved by the internal review board of the Federal German Pension Agency.

\section{RESULTS}

Table 2 shows the average scores for the items of the protocol adherence measure and the two global scales. The global item which asks whether the topic of the day has been presented is answered similarly in both groups, as this has been done in both groups alike.

There are significant differences in the sum scores of the two subscales between the treatment groups according to the treatment content (Fig. 1; Table 2). The overall ANOVA showed highly significant results for both subscales (regeneration subscale: $\mathrm{F}_{(2,259)}=25.17, \mathrm{p}<0.001$; resistance subscale: $\mathrm{F}_{(2,257)}=$ $12.26, \mathrm{p}<0.001)$. When comparing subgroups, the significant differences in the expected direction were also observed (regeneration subscale: TAU vs. RG p $<0.001$, TAU vs. RS p = 0.012 , RG vs. RS p < 0.001; resistance subscale: TAU vs. RG p $=0.82$, TAU vs. RS p $<0.001, \mathrm{RG}$ vs. RS p = 0.003).

When looking at individual items (Table 2), all regeneration items showed significant differences between the groups in the expected direction, except for 'I have tested different creative techniques for their effects on my well-being. In respect to the resistance items, no differences were observed found for 'I was trained to enhance my level of stamina in dealing with tasks', 'I learned how to cope with the burdens' and 'I learned that preservation is important while dealing with strains. Obviously, patients in the regeneration group also had, to some degree. the idea that they should learn to overcome adversities.

In comparison to the patients in routine care (TAU), significant higher regeneration scores were observed in the regeneration group and lower regeneration scores were observed in the resistance group. In respect to the resistance items, no significant differences between the routine and regeneration patients were observed, but there is a significant difference for 7 of 10 items in comparison to the resistance group. 
Table 2. Patient ratings on the therapy competency checklist (TAU: routine occupational therapy only, RG: regeneration group, RS: resistance group, scale: $1=$ not, $7=$ completelyl

\begin{tabular}{|c|c|c|c|c|c|c|c|}
\hline & $\begin{array}{l}\text { All } \\
\text { (N = } \\
259)\end{array}$ & $\begin{array}{l}\text { TAU } \\
(\mathrm{N}= \\
119)\end{array}$ & $\begin{array}{c}\text { RG } \\
(N=67)\end{array}$ & $\begin{array}{c}\text { RS } \\
(N=73)\end{array}$ & $\begin{array}{l}\text { ANOVA TAU } \\
\text { vs. RG vs. RS }\end{array}$ & T-Test TAU vs. RG \& RS & $\begin{array}{l}\text { T-Test } \\
\text { RG vs. RS }\end{array}$ \\
\hline & $\begin{array}{c}\text { mean } \\
\text { [SD] }\end{array}$ & $\begin{array}{c}\text { mean } \\
\text { (SD) }\end{array}$ & $\begin{array}{l}\text { mean } \\
\text { (SD) }\end{array}$ & $\begin{array}{l}\text { mean } \\
\text { (SD) }\end{array}$ & & & \\
\hline \multicolumn{8}{|l|}{ Regeneration } \\
\hline $\begin{array}{c}1 \text { We talked about } \\
\text { pleasant and } \\
\text { compensatory } \\
\text { activities }\end{array}$ & $\begin{array}{l}5.05 \\
(1.50)\end{array}$ & $\begin{array}{c}4.99 \\
(1.42)\end{array}$ & $\begin{array}{l}5.73 \\
(1.04)\end{array}$ & $\begin{array}{c}4.51 \\
(1.75)\end{array}$ & $\begin{array}{c}F_{(2,256)}=12.85 \\
p<0.001\end{array}$ & $\begin{array}{l}\text { TAU vs. RG ( } p=0.003) \\
\text { TAU vs. RS }(p=0.07)\end{array}$ & $\begin{array}{c}R G \text { vs. } R S(p< \\
0.001)\end{array}$ \\
\hline $\begin{array}{l}2 \text { We looked at the } \\
\text { difference between } \\
\text { former and current } \\
\text { pleasant activities }\end{array}$ & $\begin{array}{c}3.74 \\
(1.74)\end{array}$ & $\begin{array}{c}3.74 \\
(1.73)\end{array}$ & $\begin{array}{c}4.10 \\
(1.65)\end{array}$ & $\begin{array}{l}3.41 \\
(1.79)\end{array}$ & $\begin{array}{c}F_{(2,255)}=2.82 \\
p=0.06\end{array}$ & $\begin{array}{c}\text { TAU vs. RG ( } p=0.50), \text { TAU } \\
\text { vs. } R S(p=0.62)\end{array}$ & $\begin{array}{c}R G \text { vs. } R S(p< \\
0.001)\end{array}$ \\
\hline $\begin{array}{c}3 \text { We planned } \\
\text { pleasant activities } \\
\text { for the time after } \\
\text { discharge from the } \\
\text { hospital }\end{array}$ & $\begin{array}{c}3.61 \\
(1.93)\end{array}$ & $\begin{array}{c}3.68 \\
(1.95)\end{array}$ & $\begin{array}{l}4.13 \\
(1.80)\end{array}$ & $\begin{array}{c}3.04 \\
(1.88)\end{array}$ & $\begin{array}{c}F_{(2,254)}=6.03 \\
p=0.003\end{array}$ & $\begin{array}{c}\text { TAU vs. RG }(p=0.36), \text { TAU } \\
\text { vs. RS }(p=0.07)\end{array}$ & $\begin{array}{l}R G \text { vs. RS (p }= \\
0.002)\end{array}$ \\
\hline $\begin{array}{l}4 \text { I was able } \\
\text { to experience } \\
\text { moments of } \\
\text { indulgence }\end{array}$ & $\begin{array}{c}4.56 \\
(1.85)\end{array}$ & $\begin{array}{c}4.33 \\
(1.83)\end{array}$ & $\begin{array}{l}5.40 \\
(1.46)\end{array}$ & $\begin{array}{l}4.16 \\
(1.97)\end{array}$ & $\begin{array}{c}F_{(2,259)}=10.31 \\
p<0.001\end{array}$ & $\begin{array}{l}\text { TAU vs. RG }(p<0.001) \\
\text { TAU vs. RS }(p=1.00)\end{array}$ & $\begin{array}{c}R G \text { vs. } R S \text { ( } p< \\
0.001)\end{array}$ \\
\hline $\begin{array}{c}5 \text { We focussed on } \\
\text { eating as a part of } \\
\text { pleasure }\end{array}$ & $\begin{array}{l}3.59 \\
(2.20)\end{array}$ & $\begin{array}{c}3.59 \\
(1.94)\end{array}$ & $\begin{array}{l}5.16 \\
(1.44)\end{array}$ & $\begin{array}{c}2.18 \\
(1.82)\end{array}$ & $\begin{array}{c}F_{(2,259)}=49.06 \\
p<0.001\end{array}$ & $\begin{array}{l}\text { TAU vs. RG }(p<0.001) \\
\text { TAU vs. RS }(p<0.001)\end{array}$ & $\begin{array}{c}R G \text { vs. } R S(p< \\
0.001)\end{array}$ \\
\hline $\begin{array}{l}6 \text { I had nice } \\
\text { and relaxing } \\
\text { conversations with } \\
\text { the other patients }\end{array}$ & $\begin{array}{c}5.57 \\
(1.45)\end{array}$ & $\begin{array}{c}5.47 \\
(1.48)\end{array}$ & $\begin{array}{l}6.01 \\
(1.20)\end{array}$ & $\begin{array}{c}5.32 \\
(1.54)\end{array}$ & $\begin{array}{c}F_{(2,257)}=4.63 \\
p=0.01\end{array}$ & $\begin{array}{c}\text { TAU vs. RG }(p=0.04), \text { TAU } \\
\text { vs. } R S(p=1.00)\end{array}$ & $R G$ vs. $R S(p=0.01)$ \\
\hline $\begin{array}{l}7 \text { I was able to test } \\
\text { creative techniques } \\
\text { in relation to my } \\
\text { personal well-being }\end{array}$ & $\begin{array}{l}5.25 \\
(4.13)\end{array}$ & $\begin{array}{c}4.72 \\
(1.77)\end{array}$ & $\begin{array}{c}5.24 \\
(1.39)\end{array}$ & $\begin{array}{c}5.30 \\
(1.60)\end{array}$ & $\begin{array}{c}F_{(2,256)}=0.01 \\
p=0.99\end{array}$ & $\begin{array}{c}\text { TAU vs. RG }(p=1.00), \text { TAU } \\
\text { vs. } R S(p=1.00)\end{array}$ & RG vs. RS $(p=1.00)$ \\
\hline $\begin{array}{l}8 \text { We spoke about } \\
\text { my first impression } \\
\text { in social situations }\end{array}$ & $\begin{array}{l}3.13 \\
(2.19)\end{array}$ & $\begin{array}{c}2.83 \\
(2.07)\end{array}$ & $\begin{array}{c}4.81 \\
(1.92)\end{array}$ & $\begin{array}{c}2.05 \\
(1.66)\end{array}$ & $\begin{array}{c}F_{(2,253)}=38.32 \\
\quad p<0.001\end{array}$ & $\begin{array}{l}\text { TAU vs. RG }(p<0.001) \\
\text { TAU vs. RS }(p=0.02)\end{array}$ & $\begin{array}{c}R G \text { vs. } R S(p< \\
0.001)\end{array}$ \\
\hline $\begin{array}{c}9 \text { I got tips on how } \\
\text { to improve my first } \\
\text { impression }\end{array}$ & $\begin{array}{c}2.93 \\
(2.06)\end{array}$ & $\begin{array}{c}2.86 \\
(2.05)\end{array}$ & $\begin{array}{c}4.34 \\
(1.89)\end{array}$ & $\begin{array}{c}1.78 \\
(1.36)\end{array}$ & $\begin{array}{c}F_{(2,253)}=33.57 \\
p<0.001\end{array}$ & $\begin{array}{l}\text { TAU vs. RG }(p<0.001) \\
\text { TAU vs. RS }(p<0.001)\end{array}$ & $\begin{array}{c}R G \text { vs. } R S(p< \\
0.001)\end{array}$ \\
\hline $\begin{array}{l}10 \text { I was animated to } \\
\text { talk to others }\end{array}$ & $\begin{array}{c}5.02 \\
(1.74)\end{array}$ & $\begin{array}{c}4.68 \\
(1.79)\end{array}$ & $\begin{array}{c}5.75 \\
(1.21)\end{array}$ & $\begin{array}{l}4.87 \\
(1.90)\end{array}$ & $\begin{array}{c}F_{(2,208)}=7.34 \\
p=0.001\end{array}$ & $\begin{array}{l}\text { TAU vs. RG }(p=0.001) \\
\text { TAU vs. RS }(p=1.00)\end{array}$ & $R G$ vs. $R S(p=0.02)$ \\
\hline $\begin{array}{l}\text { RG scale (sum } \\
\text { score) }\end{array}$ & $\begin{array}{c}4.21 \\
(1.24)\end{array}$ & $\begin{array}{c}4.09 \\
(1.20)\end{array}$ & $\begin{array}{l}5.05 \\
(1.00)\end{array}$ & $\begin{array}{l}3.63 \\
(1.09)\end{array}$ & $\begin{array}{c}F_{(2,259)}=25.17 \\
p<0.001\end{array}$ & $\begin{array}{c}\text { TAU vs. RG }(p<0.001) \\
\text { TAU vs. RS }(p=0.01)\end{array}$ & $\begin{array}{c}R G \text { vs. } R S(p< \\
0.001)\end{array}$ \\
\hline \multicolumn{8}{|l|}{ Resistance } \\
\hline $\begin{array}{l}1 \text { I learned to } \\
\text { improve my } \\
\text { frustration } \\
\text { tolerance }\end{array}$ & $\begin{array}{c}3.81 \\
(1.75)\end{array}$ & $\begin{array}{c}3.52 \\
(1.77)\end{array}$ & $\begin{array}{c}3.92 \\
(1.55)\end{array}$ & $\begin{array}{c}4.19 \\
(1.82)\end{array}$ & $\begin{array}{c}F_{(2,256)}=3.58 \\
p=0.03\end{array}$ & $\begin{array}{c}\text { TAU vs. RG ( } p=0.39), \text { TAU } \\
\text { vs. RS ( } p=0.03)\end{array}$ & RG vs. RS $(p=1.00)$ \\
\hline
\end{tabular}


Table 2. Patient ratings on the therapy competency checklist (TAU: routine occupational therapy only, RG: regeneration group, RS: resistance group, scale: $1=$ not, $7=$ completelyl

\begin{tabular}{|c|c|c|c|c|c|c|c|}
\hline & $\begin{array}{l}\text { All } \\
\text { (N = } \\
259)\end{array}$ & $\begin{array}{l}\text { TAU } \\
\text { (N= } \\
119)\end{array}$ & $\begin{array}{c}\text { RG } \\
(N=67)\end{array}$ & $\begin{array}{c}\text { RS } \\
(N=73)\end{array}$ & $\begin{array}{l}\text { ANOVA TAU } \\
\text { vs. RG vs. RS }\end{array}$ & T-Test TAU vs. RG \& RS & $\begin{array}{l}\text { T-Test } \\
\text { RG vs. RS }\end{array}$ \\
\hline & $\begin{array}{l}\text { mean } \\
\text { (SD) }\end{array}$ & $\begin{array}{c}\text { mean } \\
\text { (SD) }\end{array}$ & $\begin{array}{c}\text { mean } \\
\text { (SD) }\end{array}$ & $\begin{array}{c}\text { mean } \\
\text { (SD) }\end{array}$ & & & \\
\hline $\begin{array}{c}2 \text { I learned to } \\
\text { improve my level of } \\
\text { detachment when I } \\
\text { get frustrated }\end{array}$ & $\begin{array}{c}4.10 \\
(1.74)\end{array}$ & $\begin{array}{l}3.95 \\
(1.72)\end{array}$ & $\begin{array}{l}4.03 \\
(1.69)\end{array}$ & $\begin{array}{c}4.41 \\
(1.79)\end{array}$ & $\begin{array}{c}F_{(2,255)}=1.68 \\
p=0.19\end{array}$ & $\begin{array}{c}\text { TAU vs. } R G(p=1.00), \text { TAU } \\
\text { vs. } R S(p=0.23)\end{array}$ & RG vs. RS ( $p=0.58)$ \\
\hline $\begin{array}{l}3 \text { I was trained to } \\
\text { enhance my level of } \\
\text { stamina in dealing } \\
\text { with tasks }\end{array}$ & $\begin{array}{c}4.01 \\
(1.77)\end{array}$ & $\begin{array}{c}3.87 \\
(1.82)\end{array}$ & $\begin{array}{l}3.81 \\
(1.64)\end{array}$ & $\begin{array}{c}4.42 \\
(1.77)\end{array}$ & $\begin{array}{c}F_{(2,256)}=2.82 \\
p=0.06\end{array}$ & $\begin{array}{c}\text { TAU vs. RG }(p=1.00), \text { TAU } \\
\text { vs. } R S(p=0.11)\end{array}$ & RG vs. RS $(p=1.00)$ \\
\hline $\begin{array}{l}4 \text { I learned that } \\
\text { preservation is } \\
\text { important while } \\
\text { dealing with strains }\end{array}$ & $\begin{array}{c}4.58 \\
(1.80)\end{array}$ & $\begin{array}{l}4.37 \\
(1.91)\end{array}$ & $\begin{array}{c}4.50 \\
(1.58)\end{array}$ & $\begin{array}{c}4.97 \\
(1.78)\end{array}$ & $\begin{array}{c}F_{(2,252)}=2.61 \\
p=0.08\end{array}$ & $\begin{array}{c}\text { TAU vs. } R G(p=1.00), \text { TAU } \\
\text { vs. } R S(p=0.08)\end{array}$ & RG vs. RS ( $p=0.37)$ \\
\hline $\begin{array}{l}5 \text { I trained my } \\
\text { adherence to } \\
\text { instructions }\end{array}$ & $\begin{array}{c}4.07 \\
(1.90)\end{array}$ & $\begin{array}{c}3.70 \\
(1.92)\end{array}$ & $\begin{array}{l}3.89 \\
(1.70)\end{array}$ & $\begin{array}{c}4.81 \\
(1.88)\end{array}$ & $\begin{array}{c}F_{(2,251)}=8.46 \\
p<0.001\end{array}$ & $\begin{array}{c}\text { TAU vs. RG }(p=1.00), \text { TAU } \\
\text { vs. } R S(p<0.001)\end{array}$ & RG vs. RS (p = 0.01) \\
\hline $\begin{array}{c}6 \text { I trained my } \\
\text { accuracy in task } \\
\text { processing }\end{array}$ & $\begin{array}{l}3.75 \\
(1.95)\end{array}$ & $\begin{array}{c}3.50 \\
(1.94)\end{array}$ & $\begin{array}{c}3.41 \\
(1.82)\end{array}$ & $\begin{array}{l}4.43 \\
(1.94)\end{array}$ & $\begin{array}{c}F_{(2,252)}=6.73 \\
p=0.001\end{array}$ & $\begin{array}{c}\text { TAU vs. } R G(p=1.00), \text { TAU } \\
\text { vs. } R S(p<0.001)\end{array}$ & RG vs. RS $(p=0.01)$ \\
\hline $\begin{array}{l}7 \text { I trained my } \\
\text { discomfort } \\
\text { tolerance }\end{array}$ & $\begin{array}{c}3.38 \\
(1.94)\end{array}$ & $\begin{array}{c}3.03 \\
(1.94)\end{array}$ & $\begin{array}{l}3.24 \\
(1.79)\end{array}$ & $\begin{array}{c}4.10 \\
(1.91)\end{array}$ & $\begin{array}{c}F_{(2,255)}=7.46 \\
p=0.001\end{array}$ & $\begin{array}{c}\text { TAU vs. SP ( } p=1.00), \text { TAU } \\
\text { vs. } R S(p=0.02)\end{array}$ & RG vs. RS ( $p=0.02)$ \\
\hline $\begin{array}{c}8 \mathrm{I} \text { have increased } \\
\text { my readiness to } \\
\text { overcome personal } \\
\text { deficits }\end{array}$ & $\begin{array}{c}3.52 \\
(1.81)\end{array}$ & $\begin{array}{l}3.13 \\
(1.68)\end{array}$ & $\begin{array}{l}3.55 \\
(1.85)\end{array}$ & $\begin{array}{c}4.12 \\
(1.82)\end{array}$ & $\begin{array}{c}F_{(2,251)}=7.06 \\
p=0.001\end{array}$ & $\begin{array}{c}\text { TAU vs. RG }(p=0.39), \text { TAU } \\
\text { vs. } R S(p<0.001)\end{array}$ & RG vs. RS ( $p=0.17)$ \\
\hline $\begin{array}{c}9 \text { I learned to } \\
\text { endure unpleasant } \\
\text { tasks }\end{array}$ & $\begin{array}{c}3.85 \\
(1.92)\end{array}$ & $\begin{array}{c}3.17 \\
(1.82)\end{array}$ & $\begin{array}{c}3.70 \\
(1.79)\end{array}$ & $\begin{array}{c}5.04 \\
(1.63)\end{array}$ & $\begin{array}{c}F_{(2,254)}= \\
25.74, p< \\
0.001\end{array}$ & $\begin{array}{c}\text { TAU vs. } R G(p=0.15), \text { TAU } \\
\text { vs. } R S(p<0.001)\end{array}$ & $\begin{array}{c}\text { RG vs. } R S(p< \\
0.001)\end{array}$ \\
\hline $\begin{array}{l}10 \text { I was able } \\
\text { to improve my } \\
\text { flexibility }\end{array}$ & $\begin{array}{c}4.33 \\
(1.79)\end{array}$ & $\begin{array}{l}3.89 \\
(1.78)\end{array}$ & $\begin{array}{l}4.30 \\
(1.64)\end{array}$ & $\begin{array}{l}5.05 \\
(1.71)\end{array}$ & $\begin{array}{c}\mathrm{F}_{(2,255)}= \\
10.37, \mathrm{p}< \\
0.001\end{array}$ & $\begin{array}{c}\text { TAU vs. } R G(p=0.37), \text { TAU } \\
\text { vs. } R S(p<0.001)\end{array}$ & RG vs. RS $(p=0.03)$ \\
\hline $\begin{array}{l}\text { RS scale (sum } \\
\text { score) }\end{array}$ & $\begin{array}{c}3.93 \\
(1.36)\end{array}$ & $\begin{array}{l}3.60 \\
(1.26)\end{array}$ & $\begin{array}{c}3.82 \\
(1.29)\end{array}$ & $\begin{array}{c}4.55 \\
(1.40)\end{array}$ & $\begin{array}{c}F_{(2,257)}= \\
12.26, p< \\
0.001\end{array}$ & $\begin{array}{c}\text { TAU vs. } R G(p=0.82), \text { TAU } \\
\text { vs. } R S(p<0.001)\end{array}$ & $\begin{array}{c}R G \text { vs. } R S(p= \\
0.003)\end{array}$ \\
\hline $\begin{array}{l}\text { I was asked in all } \\
\text { sessions to refer to } \\
\text { the topic of the day }\end{array}$ & $\begin{array}{c}4.23 \\
(2.17)\end{array}$ & - & $\begin{array}{c}4.28 \\
(2.17)\end{array}$ & $\begin{array}{c}4.20 \\
(2.25)\end{array}$ & $\begin{array}{c}F_{(2,253)}=0.01 \\
p=0.99\end{array}$ & - & RG vs. RS ( $p=0.99)$ \\
\hline
\end{tabular}

\section{DISCUSSION}

This, to our knowledge, is the first study that standardised and manualised two different treatment approaches in occupational therapy and assesses protocol adherence in a hospital setting. The two manuals describe two treatment modes that are widely used in ergotherapy for patients with mental disorders. The support of regeneration, recreation, relaxation, distraction and positive activities are frequent interventions in occupational therapy (Pollänen, 2015). The same is true for the training of skills and capacities, endurance, hardiness, stress tolerance and the ability to work. 


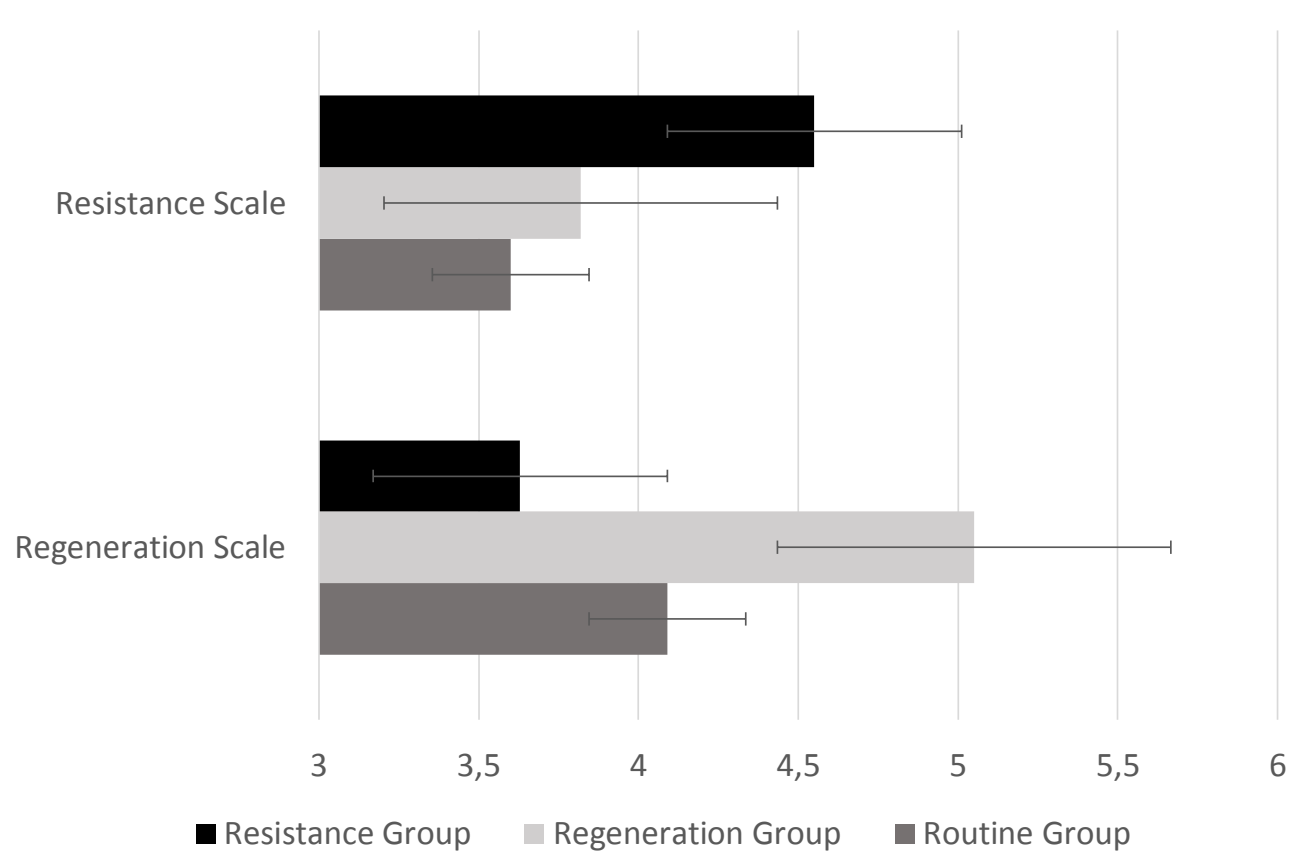

Figure 1. Sum scores of the BTCC subscales for regeneration and resistance-oriented ratings in the TAU, RG and RS groups, indicating the amount of respective interventions per treatment group.

The study shows that it is possible to describe different treatment processes with different therapeutic focuses in occupational therapy in a manual and that occupational therapists are able to learn and apply different treatment rationales and provide treatment according to the protocol. This is the prerequisite for the development of different occupational treatments for the targeting of treatment according to the needs of different disorders (Ikiugu \& Nissen, 2016). It is also important in the education of occupational therapists.

The study also shows that it is possible to measure protocol adherence in occupational therapy. The measurement of protocol adherence, as used in this study, is of high validity, as it does not refer to ratings of therapists but of patients. When the therapists are asked about their treatment, they may report what they intended to do. This is not necessarily what they did. What is more important is what patients recognised and experienced during the treatment. From this perspective, there were different interventions in both groups, as the data show significant and meaningful differences between groups on the protocol adherence scale.

Once it is possible to measure and ascertain treatment according to protocol, it is possible to study which treatment is best for which patient and has which result, similar to that done in other forms of psychotherapy. Occupational therapy can and should be evidence based like all other treatments (Myers \& Lotz, 2017).

Limitations of the study are that it has been done in a specific inpatient setting, with special treatments and with well-trained occupational therapists, so that results might be different under other circumstances. In future studies, observational ratings could be of interest.

\section{COMPETING INTEREST STATEMENT}

The authors have no competing interest to report.

\section{ETHICAL APPROVAL}

All procedures performed in studies involving human participants were in accordance with the ethical standards of the institutional and/or national research committee and with the 1964 Helsinki declaration and its later amendments or comparable ethical standards.

\section{INFORMED CONSENT}

Informed consent was obtained from all individual participants included in the study. 


\section{FUNDING}

The study has been supported by a research grant of the Federal German Pension Fnd.

\section{DATA AVAILABILITY STATEMENT}

The data set can be sent by the editorial office of the Research Group Psychosomatic Rehabilitation upon request to fpr@ charite.de.

\section{REFERENCES}

Barclay-Goddard RE, Stevenson TJ, Thalman L, \& Poluha W (2011). Mental practice for treating upper extremity deficits in individuals with hemiparesis after stroke. Stroke, 42(11), 574-575. doi: 10.1161/STROKEAHA.111.627414

Barlow J,\& Parsons J (2003). Group-based parent-training programmes for improving emotional and behavioural adjustment in 0-3 year old children. New York, NY: Cochrane Collaboration, Wiley \& Sons.

Blackwell B, Edel, MA, Armgart C, Emons B, Kulik A, Graßnickel V, Schaub M, Haußleiter IS, Roser P, \& Juckel, G (2012). Antidepressive Wirksamkeit von Ergotherapie als Add-OnBehandlung der majoren Depression. Available from: http://www. lwl.org/psychiatrieverbund-download/pdf/Poster_Blackwell.pdf. Accessed November 2015.

Bryant W, Fieldhouse J, \& Bannigan K (2014). Creek's Occupational Therapy and Mental Health (5 $5^{\text {th }}$ Edition). Edinburgh, Scotland: Churchill Livingstone, Elsevier.

Buchain PC, Vizzotto AD, Henna Neto J,\& Elkis H (2003). Randomized controlled trial of occupational therapy in patients with treatment-resistant schizophrenia. Revista Brasileira Psiquiatria, 25(1), 26-30. doi: 10.1590/S1516-44462003000100006

Dooley NR,\& Hinojosa J (2004). Improving quality of life for persons with Alzheimer's disease and their family caregivers: Brief occupational therapy intervention. American Journal of Occupational Therapy, 58(5), 561-569. doi:10.5014/ajot.58.5.561

DRV, Deutsche Rentenversicherung Bund (2012). Anforderungsprofil zur Durchführung der medizinisch beruflich orientierten Rehabilitation (MBOR) im Auftrag der Deutschen Rentenversicherung. Berlin, Germany: DRV-Bund.

\section{ACKNOWLEDGEMENT}

The language of the manuscript has been revised by Cognoscenti Proofreading, Leeds, UK, without changes in the content.
DVE, Deutscher Verband der Ergotherapeuten (Beschäftigungsund Arbeitstherapeuten e.V.) (1995). Indikationskatalog Ergotherapie. Idstein, Germany: Schulz-Kirchner.

Fava G, \& Tomba E (2009). Increasing Well-Being and Resilience by Psychotherapeutic Method. Journal of Personality, 77(6), 19031933. doi: 10.1111/j.1467-6494.2009.00604.x

Flückiger C, Regli D, Zwahlen D, Hostettler S, \& Casper F (2015). Der Berner Patienten- und Therapeutenstundenbogen 2000. Zeitschrift für Klinische Psychologie und Psychotherapie, 39(2), 71-79.

Foxcroft DR, Ireland D, Lister Sharp DJ, Lowe G, \& Breen R (2003). Longer term primary prevention for alcohol misuse in young people: A systematic review. Addiction, 98(4), 397-411. doi: 10.1046/j.1360-0443.2003.00355.x

Graff MJL, Adang EMM, Vernooij-Dassen MJM, Dekker J, Jönsson L, Thijssen M, Hoefnagels WHL, \& Rikkert MG (2008). Community Occupational Therapy for Older Patients with Dementia and Their Care Givers: Cost Effectiveness Study. BMJ, 336(7636), 134-138. doi: 10.1136/bmj.39408.481898.BE

Hillert A, Müller-Fahrnow W, \& Radoschewski M (2009). Medizinisch-beruflichorientierte Rehabilitation. Köln, Germany: Deutscher Ärzteverlag.

Hogan VM, Lisy, ED, Savannah RL, Henry L, Kuo F, \& Fisher GS (2004). Role change experienced by family caregivers of adults with Alzheimer's disease: Implications for occupational therapy. Physical and Occupational Therapy in Geriatrics, 22(1), 21-43. doi: 10.1080/J148v22n01_02

Horvath AO, \&Greenberg LS (1986). The development of the Working Alliance Inventory. In L Greenberg, \&W Pinsof (Eds.), The psychotherapeutic process: A resource handbook(pp. 529-556). New York, NY: Guilford Press. 
Höger D, \& Eckert J (1997). Der Bielefelder KlientenErfahrungsbogen (BIKEB). Ein Verfahren zur Erfassung von Aspekten des „Post-Session Outcome“ bei Psychotherapien. Zeitschriftfür Klinische Psychologie, 26(1), 129-137.

Ikiugu MN, \& Nissen, RM (2016). Intervention Strategies Used by Occupational Therapists Working in Mental Health and Their Theoretical Basis. Occupational Therapy in Mental Health, 32(2), 109-129.

Jerosch-Herold C, Marotzki U, Hack BM, \& Weber P (1999). Konzeptionelle Modelle für dieergotherapeutische Praxis. Berlin, Germany: Springer.

Kobasa S (1979). Stressful Life Events, Personality, and Health: An Inquiry into Hardiness. Journal of Personality and Social Psychology, 37(1), 1-11. doi: 10.1037/0022-3514.37.1.1

Lawton MP (1997). Assessing quality of life in Alzheimer disease research. Alzheimer Disability and Associated Disorders, 11(6), 91-99.

Linden M, \& Gehrke G (2013). Therapieziele und Therapieoptionen einer verhaltenstherapeutisch orientierten Ergotherapie. Verhaltenstherapie, 23(1), 6-11. doi:10.1159/000348596

Linden M,\& Langhoff C (2010). Verhaltenstherapie-KompetenzCheckliste. Psychotherapeut, 55(6), 477-484. doi: 10.1007/s00278010-0775-2

Linden, M., Langhoff, C. \& Rotter, M. (2007). Definition, operationalization, and quality assurance of psychotherapy. An investigation with the behaviour therapy-competence-checklist (BTCC). Psychiatria Danubina, 19, 308 -316.

Linden M,\& Weig W (2009). Salutotherapie. Köln, Germany: Deutscher Ärzteverlag.

Lutz R (2008).Genussgruppe: „Kleine Schule des Genießens“. In M Linden, \& M Hautzinger (Eds.), Verhaltenstherapiemanual (pp. 352-355).Heidelberg, Germany: Springer.

Neil AL, \& Christensen H (2007). Australian school-based prevention and early intervention programs for anxiety and depression: a systematic review. The Medical Journal of Australia,186(6), 305-308.

Myers CT, \& Lotz J (2017). Practitioner training for use of evidencebased practice in occupational therapy. Occupational Therapy in Health Care, 31(3), 214-237.
Pohl U, Richter H, \& Bohus M. (2000). Neuere Entwicklungen zur systematischen Überprüfung des therapeutischen Vorgehens. Psychotherapie PsychosomatikMedizinische Psychologie, 50(1), 14-21. doi: 10.1055/s-2000-13234

Pöllänen S (2015). Elements of Crafts that Enhance Well-Being. Journal of Leisure Research, 47(1), 58-78.

Presber W (2003). Ergotherapie: Grundlagen und Techniken. München, Germany: Elsevier, Urban \& Fischer Press.

Reuster T (2006). Effektivität der Ergotherapie im psychiatrischen Krankenhaus: Mit einer Synopse zu Geschichte, Stand und aktueller Entwicklung der psychiatrischen Ergotherapie. Monographien aus dem Gesamtgebiete der Psychiatrie. Darmstadt, Germany: Steinkopff.

Steultjens EM, Dekker J, Bouter LM, Leemrijse CJ, \& van den Ende $\mathrm{CH}$ (2005). Evidence of the efficacy of occupational therapy in different conditions: An overview of systematic reviews. Clinical Rehabilitation, 19(3), 247-254. doi: 10.1191/0269215505cr870oa

Staats M, Bär T, \&Linden M (2003). Messinstrumente der Therapeutencompliance in der Verhaltenstherapie. Verhaltenstherapie, 13(1), 62-67. doi: 10.1159/000070500

Szucs KA, Benson JD, \& Haneman B (2017). Using a guided journal club as a teaching survey to enhance learning skills for evidencebased practice. Occupational Therapy in Health Care, 31 (2), 143 149

Waddell C, Hua JM, Garland OM, Peters R, \& McEwan K (2007). Preventing mental disorders in children: a systematic review to inform policy-making. Canadian Journal of Public Health, 98(3), 166-173.

WFOT, World Federation of Occupational Therapists (2010). Statement on Occupational Therapy. Forrestfield, Australia: WFOT.

Willutzki U, Ülsmann D., Schulte D, \& Veith A (2013). Direkte Veränderungsmessung in der Psychotherapie. Der Bochumer Veränderungsbogen-2000 (BVB-2000). Zeitschrift für Klinische Psychologie und Psychotherapie, 42(4), 256-268.

Zarafonitis-Müller S, Kuhr K, \& Bechdolf A (2014). The Relationship between Therapist's Competence and Adherence to Outcome in Cognitive-Behavioural Therapy - Results of a Metaanalysis. Fortschritte in der Neurologie und Psychiatrie, 82(9), 502-510. doi: 10.1055/s-0034-1366798 
Treatment Manual

"Regeneration Training"

1st Session

Basic module

\begin{tabular}{|c|c|c|c|}
\hline Time (Min) & Contents & Materials & Tasks of Therapist \\
\hline $0-5^{\prime}$ & Welcoming of participants & List of participants, & $\begin{array}{l}\text { Check the list of participants, } \\
\text { welcome new participants }\end{array}$ \\
\hline $5^{\prime}-30^{\prime}$ & $\begin{array}{c}\text { Presentation of the RADL list (Recreational Activi- } \\
\text { ties of Daily Living), What is it about? Explanation of } \\
\text { the general framework lactivities despite impair- } \\
\text { ment, What comes to my mind when filling in the } \\
\text { list? }\end{array}$ & $\begin{array}{l}\text { completion of RADL list } \\
\text { by each participant }\end{array}$ & $\begin{array}{c}\text { Collect ideas by of participants, } \\
\text { support the exchange of personal } \\
\text { experiences }\end{array}$ \\
\hline $30^{\prime}-40^{\prime}$ & $\begin{array}{l}\text { Focus of collection on recreational activities in the } \\
\text { past (each participant writes down at least } 3 \text { activi- } \\
\text { ties) }\end{array}$ & $\begin{array}{l}\text { Pencil and paper for } \\
\text { each participant }\end{array}$ & $\begin{array}{l}\text { Support the exchange of experi- } \\
\text { ences and give examples }\end{array}$ \\
\hline $40^{\prime}-85^{\prime}$ & $\begin{array}{l}\text { Specify individual goals (.Which pleasant things do I } \\
\text { want to do again?“) }\end{array}$ & $\begin{array}{l}\text { Pencil and paper for } \\
\text { each participant }\end{array}$ & $\begin{array}{l}\text { Make sure that discussion is } \\
\text { focused on exchange, without } \\
\text { evaluation, reinforce small pro- } \\
\text { gresses and ideas }\end{array}$ \\
\hline $85^{\prime}-90^{\prime}$ & $\begin{array}{l}\text { Summary of session and explanation of treatment } \\
\text { topic: „Here you can learn to take care of yourself } \\
\text { when stressed”. Termination of session }\end{array}$ & List of participants & Give a summary. \\
\hline
\end{tabular}

2nd Session

Recreational activities

Motto of the day: „Recreational activities“

\begin{tabular}{|c|l|}
\hline$\square$ & Under stress you need recreation \\
\hline$\square$ & Always keep a balance between work and leisure \\
\hline$\square$ & There is a time for everything, work and relaxation \\
\hline$\square$ & Creativity is pleasure, which pretends to be work \\
\hline$\square$ & \\
\hline
\end{tabular}

Here I need recreational activities to compensate stress:

\begin{tabular}{|c|c|c|c|}
\hline Time (Min) & Contents & Materials & Tasks of Therapist \\
\hline $0-5^{\prime}$ & $\begin{array}{c}\text { Welcoming of participants, } \\
\text { Reiterate motto of the day }\end{array}$ & List of participants, & $\begin{array}{c}\text { Check the list of participants, } \\
\text { welcome new participants }\end{array}$ \\
\hline $5^{\prime}-30^{\prime}$ & $\begin{array}{c}\text { Refer to RADL list, now we do the transfer into real life } \\
\text { Presentation of the weekly activity schedule, Every } \\
\text { participant fills in a plan for the next week. Quantity is } \\
\text { less important than performance }\end{array}$ & $\begin{array}{c}\text { For each patient a } \\
\text { template of a weekly } \\
\text { activity schedule, pencils }\end{array}$ & $\begin{array}{c}\text { Collect ideas by interviewing } \\
\text { the participants, support } \\
\text { exchange of ideas }\end{array}$ \\
\hline $30^{\prime}-50^{\prime}$ & fill in the activity schedule & $\begin{array}{c}\text { Help participants to fill in the } \\
\text { schedule, reinforce creativity } \\
\text { and little progresses }\end{array}$ \\
\hline $50^{\prime}-65^{\prime}$ & $\begin{array}{r}\text { Evaluation of weekly schedule for each category of the } \\
\text { RADL. }\end{array}$ & $\begin{array}{c}\text { Summarize main categories, } \\
\text { reinforce own ideas and } \\
\text { progress }\end{array}$ \\
\hline $65^{\prime}-80^{\prime}$ & $\begin{array}{r}\text { Set up groups participants according to favorite } \\
\text { activities (Are there persons, who do things together? } \\
\text { lgo to cinema, go out for a mea). Arrangement of } \\
\text { appointments }\end{array}$ & $\begin{array}{c}\text { Write appointments on } \\
\text { flipchart }\end{array}$ & $\begin{array}{c}\text { Stimulate openness, record } \\
\text { appointments, praise ideas } \\
\text { and progresses }\end{array}$ \\
\hline $80^{\prime}-9$ & $\begin{array}{r}\text { Summary of session and explanation of treatment } \\
\text { topic: ,. Here you can learn to take care of yourself when } \\
\text { stressed”. Termination of session }\end{array}$ & List of participants & Give a summary. \\
\hline
\end{tabular}


3rd Session

Recreational activities

\begin{tabular}{|c|c|c|c|}
\hline Time (Min) & Contents & Materials & Tasks of Therapist \\
\hline $0-5^{\prime}$ & $\begin{array}{l}\text { Welcoming of participants, } \\
\text { Reiterate motto of the day }\end{array}$ & List of participants, & $\begin{array}{l}\text { Check the list of participants, } \\
\text { welcome new participants }\end{array}$ \\
\hline $5^{\prime}-20^{\prime}$ & $\begin{array}{c}\text { Summary of current state of knowledge. Why } \\
\text { are pleasant activities important? What did I } \\
\text { already learn? }\end{array}$ & $\begin{array}{l}\text { Individual materials on the } \\
\text { topic of .spontaneous and } \\
\text { recreational activities“ }\end{array}$ & $\begin{array}{l}\text { Collect ideas by interviewing } \\
\text { the participants, support the } \\
\text { exchange of ideas }\end{array}$ \\
\hline $20^{\prime}-40^{\prime}$ & $\begin{array}{c}\text { Work on an individual weekly schedule for the } \\
\text { time after treatment, completion of RADL, How } \\
\text { to put the ideas in practice }\end{array}$ & $\begin{array}{c}\text { Empty weekly schedule. RADL } \\
\begin{array}{c}\text { list for the time after the end } \\
\text { of therapy, pencils }\end{array}\end{array}$ & $\begin{array}{l}\text { Help participants if needed, } \\
\text { reinforce creativity and small } \\
\text { progresses }\end{array}$ \\
\hline $40^{\prime}-50^{\prime}$ & $\begin{array}{l}\text { Presentation of the concept of a „hedonistic } \\
\text { niche“. How could a respective room look like? }\end{array}$ & $\begin{array}{l}\text { Pictures of different rooms } \\
\text { from furniture catalogues }\end{array}$ & $\begin{array}{l}\text { Guide open discussion, } \\
\text { appreciate also minor details } \\
\text { (e.g. flowers, candles etc.) }\end{array}$ \\
\hline $50^{\prime}-85^{\prime}$ & $\begin{array}{l}\text { How can I establish a hedonistic niche in my } \\
\text { room? } \\
\text { Set up small groups of patients to discuss } \\
\text { solutions }\end{array}$ & $\begin{array}{c}\text { Worksheets for } \\
\text { documentation of events and } \\
\text { own ideas }\end{array}$ & $\begin{array}{l}\text { Specify solutions, reinforce } \\
\text { even small steps, focus only on } \\
\text { positive aspects }\end{array}$ \\
\hline $80^{\prime}-90^{\prime}$ & $\begin{array}{c}\text { Summary of session and explanation of } \\
\text { treatment topic: „Here you can learn to take } \\
\text { care of yourself when stressed”. Termination } \\
\text { of session }\end{array}$ & List of participants & Give a summary. \\
\hline
\end{tabular}

\section{4th Session}

Recreational activities

\begin{tabular}{|c|c|c|c|}
\hline Time (Min) & Contents & Materials & Tasks of Therapist \\
\hline $0-5^{\prime}$ & $\begin{array}{l}\text { Welcoming of participants, } \\
\text { Reiterate motto of the day }\end{array}$ & List of participants, & $\begin{array}{l}\text { Check the list of participants, } \\
\text { welcome new participants }\end{array}$ \\
\hline $5^{\prime}-70^{\prime}$ & $\begin{array}{l}\text { Present creative activities, painting, nitting, } \\
\text { handycraft, etc., refer to RADL list, what have I } \\
\text { done in former times? } \\
\text { Motivate patients to try out new techniques }\end{array}$ & $\begin{array}{l}\text { Materials for craft activity, } \\
\text { RADL list of participant }\end{array}$ & $\begin{array}{c}\text { Encourage patient to freely try out, } \\
\text { give instructions if needed, also } \\
\text { encourage to interact }\end{array}$ \\
\hline $70^{\circ}-80^{\circ}$ & Presentation of results, exchange in the group & & $\begin{array}{c}\text { Guide open discussion, appreciate } \\
\text { also minor details }\end{array}$ \\
\hline $80^{\prime}-90^{\prime}$ & $\begin{array}{c}\text { Summary of session and explanation of } \\
\text { treatment topic: „Here you can learn to take } \\
\text { care of yourself when stressed”. Termination } \\
\text { of session }\end{array}$ & List of participants & Give a summary. \\
\hline
\end{tabular}

\section{5th Session}

\section{Ability to relish and hedonic rules}

\section{Motto of the day: „Ability to relish and hedonic rules“}

\begin{tabular}{|c|l|}
\hline$\square$ & Meals are a wonderful opportunity to make me happy \\
\hline$\square$ & Eating is more than just taking in food. \\
\hline$\square$ & If you feel bad, spoil yourself \\
\hline$\square$ & Feeling, tasting and smelling can all cheer you up. \\
\hline$\square$ & \\
\hline
\end{tabular}

The ability to relish is important in these areas and situations in life: 


\begin{tabular}{|c|c|c|c|}
\hline Time (Min) & Contents & Materials & Tasks of Therapist \\
\hline $0-5^{\prime}$ & $\begin{array}{l}\text { Welcoming of participants, } \\
\text { Reiterate motto of the day }\end{array}$ & List of participants, & $\begin{array}{l}\text { Check the list of participants, } \\
\text { welcome new participants }\end{array}$ \\
\hline $5^{\prime}-25^{\prime}$ & $\begin{array}{l}\text { What does eating mean? } \\
\text { Eating as a source of well-being, clarify the } \\
\text { difference to nutrition counselling }\end{array}$ & & $\begin{array}{l}\text { Guide a brainstorming of } \\
\text { patients, reinforce good ideas }\end{array}$ \\
\hline $20^{\prime}-25^{\prime}$ & $\begin{array}{l}\text { Set up small groups of patients. What does eating } \\
\text { mean for me? Discuss regional differences, } \\
\text { exchange of information on special meals and } \\
\text { methods of preparation, personal rituals: Which } \\
\text { meal is the most important for me? }\end{array}$ & $\begin{array}{l}\text { Map of the country/world, } \\
\text { indicate the origin of } \\
\text { participants, worksheet } \\
\text { to collect individual eating } \\
\text { rituals }\end{array}$ & $\begin{array}{l}\text { Reinforce interest in unknown } \\
\text { meals }\end{array}$ \\
\hline $35^{\prime}-45^{\prime}$ & $\begin{array}{c}\text { Evaluation of group work } \\
\text { What was special in each group? What was new, } \\
\text { what did I learn? }\end{array}$ & & $\begin{array}{l}\text { Summarize results, create a } \\
\text { calm and relaxing atmosphere }\end{array}$ \\
\hline $45^{\prime}-80^{\prime}$ & $\begin{array}{l}\text { Exercise with scents, refer to hedonic rules, what } \\
\text { was pleasant and why? }\end{array}$ & $\begin{array}{l}\text { „sample of aromas“, } \\
\text { worksheet with hedonic rules }\end{array}$ & $\begin{array}{l}\text { Focus on pleasant experiences, } \\
\text { transfer into real life, what does } \\
\text { this smell remind me of? }\end{array}$ \\
\hline $80^{\prime}-90^{\prime}$ & $\begin{array}{c}\text { Summary of session and explanation of treatment } \\
\text { topic: „Here you can learn to take care of yourself } \\
\text { when stressed”. Termination of session }\end{array}$ & List of participants & Give a summary. \\
\hline
\end{tabular}

\section{6th Session}

Ability to relish and hedonic rules

\begin{tabular}{|c|c|c|c|}
\hline Time (Min) & Contents & Materials & Tasks of Therapist \\
\hline $0-5^{\prime}$ & $\begin{array}{c}\text { Welcoming of participants, } \\
\text { Reiterate motto of the day }\end{array}$ & List of participants, & $\begin{array}{c}\text { Check the list of participants, welcome new } \\
\text { participants }\end{array}$ \\
\hline $5^{\prime}-15^{\prime}$ & Repeat hedonic rule & worksheet with hedonic rules & Encourage repetition \\
\hline $15^{\prime}-65^{\prime}$ & $\begin{array}{c}\text { Set up small groups, preparation of } \\
\text { different spreads }\end{array}$ & $\begin{array}{c}\text { worksheet with recipes, } \\
\text { ingredients for spreads }\end{array}$ & $\begin{array}{c}\text { Encourage patients to communicate } \\
\text { and have small talk, appreciate small } \\
\text { progresses }\end{array}$ \\
\hline $65^{\prime}-85^{\prime}$ & $\begin{array}{c}\text { Jointly eating of prepared foods, } \\
\text { eat slowly, concentrate on taste and } \\
\text { concomitant emotions }\end{array}$ & $\begin{array}{c}\text { Cutlery and plates, nice } \\
\text { background music }\end{array}$ & $\begin{array}{c}\text { Join the conversation of participants, } \\
\text { discriminate differences in tastes, focus on } \\
\text { pleasant experiences }\end{array}$ \\
\hline $85^{\prime}-90^{\prime}$ & $\begin{array}{c}\text { Summary of session and explanation of } \\
\text { treatment topic: ., Here you can learn to } \\
\text { take care of yourself when stressed”. } \\
\text { Termination of session }\end{array}$ & List of participants & Give a summary. \\
\hline
\end{tabular}

7th Session

Ability to relish and hedonic rules

\begin{tabular}{|c|c|c|c|}
\hline Time (Min) & Contents & Materials & Tasks of Therapist \\
\hline $0-5^{\prime}$ & $\begin{array}{r}\text { Welcoming of participants, } \\
\text { Reiterate motto of the day }\end{array}$ & List of participants, & $\begin{array}{c}\text { Check the list of participants, } \\
\text { welcome new participants }\end{array}$ \\
\hline $5^{\prime}-15^{\prime}$ & $\begin{array}{c}\text { What is important for a good meal except the } \\
\text { food: table decoration, how does my table at } \\
\text { home look like? }\end{array}$ & $\begin{array}{c}\text { Show pictures of different } \\
\text { tables }\end{array}$ & $\begin{array}{c}\text { Motivate participants to exchange } \\
\text { thoughts about .pleasant/ } \\
\text { unpleasant" table decoration }\end{array}$ \\
\hline $15^{\prime}-80^{\prime}$ & $\begin{array}{c}\text { Preparation of a table decoration as group } \\
\text { activity, seasonal differences? (Easter, spring, } \\
\text { summer) }\end{array}$ & $\begin{array}{c}\text { Serviettes, fabric belts, } \\
\text { other decoration materials, } \\
\text { flowers etc. }\end{array}$ & $\begin{array}{c}\text { Support group activities, review } \\
\text { feasibility, appreciate proposals, } \\
\text { encourage casual exchange }\end{array}$ \\
\hline $80^{\prime}-90^{\prime}$ & $\begin{array}{r}\text { Summary of session and explanation of } \\
\text { treatment topic: .Here you can learn to take } \\
\text { care of yourself when stressed”. Termination } \\
\text { of session }\end{array}$ & List of participants & Give a summary. \\
\hline
\end{tabular}


8th Session

Self-care and relaxation

My motto of the day on the topic of: "Self-care and relaxation"

\begin{tabular}{|l|l|}
\hline$\square$ & Recover energy by pampering yourself \\
\hline$\square$ & To avoid decay means to maintain \\
\hline$\square$ & I spoil myself, because I am worth it \\
\hline$\square$ & Before you can help others, you must help yours \\
\hline$\square$ & feel the power you gain from calmness \\
\hline$\square$ & \\
\hline
\end{tabular}

In these areas of life it is very important for me to care for myself and relax:

\begin{tabular}{|c|c|c|c|}
\hline Time (Min) & Contents & Materials & Tasks of Therapist \\
\hline $0-5^{\prime}$ & $\begin{array}{l}\text { Welcoming of participants, } \\
\text { Reiterate motto of the day }\end{array}$ & List of participants, & $\begin{array}{l}\text { Check the list of participants, } \\
\text { welcome new participants }\end{array}$ \\
\hline $5^{\prime}-20^{\prime}$ & $\begin{array}{l}\text { Presentation of hedonic rules, } \\
\text { exchange of own ideas }\end{array}$ & $\begin{array}{l}\text { Individual materials on the } \\
\text { topic of: „ability to relish“ }\end{array}$ & $\begin{array}{l}\text { Give information on hedonic } \\
\text { rules }\end{array}$ \\
\hline $20^{\prime}-25^{\prime}$ & $\begin{array}{l}\text { Presentation of paraffin bath and focus on } \\
\text { practicing an hedonic rule }\end{array}$ & $\begin{array}{l}\text { Pencil for patients to tick off } \\
\text { one hedonic rule }\end{array}$ & $\begin{array}{l}\text { only one aspect should be } \\
\text { practised }\end{array}$ \\
\hline $25^{\prime}-70^{\prime}$ & Paraffin bath with pleasant and relaxing music & $\begin{array}{l}\text { Paraffin bath, gloves, } \\
\text { disinfectant }\end{array}$ & $\begin{array}{l}\text { Help participants to } \\
\text { concentrate on results of } \\
\text { paraffin, create a calm and } \\
\text { relaxing atmosphere }\end{array}$ \\
\hline $70^{\prime}-80^{\prime}$ & $\begin{array}{c}\text { Which hedonic rule do I want to practice this } \\
\text { week? (transfer in real life) }\end{array}$ & $\begin{array}{l}\text { A pencil and small index } \\
\text { cards for every patient to } \\
\text { write down the hedonic rule } \\
\text { he wants to practice }\end{array}$ & \\
\hline $80^{\prime}-90^{\prime}$ & $\begin{array}{c}\text { Summary of session and explanation of treatment } \\
\text { topic: „Here you can learn to take care of yourself } \\
\text { when stressed”. Termination of session }\end{array}$ & List of participants & Give a summary. \\
\hline
\end{tabular}

\section{9th Session}

Self-care and relaxation

\begin{tabular}{|c|c|c|c|}
\hline Time (Min) & Contents & Materials & Tasks of Therapist \\
\hline $0-5^{\prime}$ & $\begin{array}{l}\text { Welcoming of participants, } \\
\text { Reiterate motto of the day }\end{array}$ & List of participants, & $\begin{array}{l}\text { Check the list of participants, } \\
\text { welcome new participants }\end{array}$ \\
\hline $5^{\prime}-45^{\prime}$ & $\begin{array}{l}\text { Introduction to tea ceremony, calm and relaxing } \\
\text { music in the background, different kinds of tea }\end{array}$ & $\begin{array}{l}\text { Tea kettle, cups, supplies } \\
\text { (candy, honey), cutlery, } \\
\text { music player, lemon juice, } \\
\text { evaporated milk }\end{array}$ & let the group have a chat \\
\hline $45^{\prime}-60^{\prime}$ & $\begin{array}{c}\text { Debriefing of tea ceremony, what was pleasant? } \\
\text { Reference to hedonic rules }\end{array}$ & $\begin{array}{l}\text { Individual materials on } \\
\text { hedonic rules }\end{array}$ & Focus on pleasant experiences \\
\hline $60^{\circ}-80^{\prime}$ & $\begin{array}{c}\text { General information about tea, cultural } \\
\text { characteristics (far eastern countries), exchange } \\
\text { of experiences/knowledge in patient group, on the } \\
\text { basis of journeys, reading }\end{array}$ & & $\begin{array}{c}\text { Give information about tea and } \\
\text { simultaneously include ideas of } \\
\text { the patients }\end{array}$ \\
\hline $80^{\prime}-90^{\prime}$ & $\begin{array}{c}\text { Summary of session and explanation of treatment } \\
\text { topic: „Here you can learn to take care of yourself } \\
\text { when stressed”. Termination of session }\end{array}$ & List of participants & Give a summary. \\
\hline
\end{tabular}


10th Session

Self-care and relaxation

\begin{tabular}{|c|c|c|c|}
\hline Time (Min) & Contents & Materials & Tasks of Therapist \\
\hline $0-5^{\prime}$ & $\begin{array}{c}\text { Welcoming of participants, } \\
\text { Reiterate motto of the day }\end{array}$ & List of participants, & $\begin{array}{c}\text { Check the list of participants, welcome } \\
\text { new participants }\end{array}$ \\
\hline $5^{\prime}-15^{\prime}$ & $\begin{array}{c}\text { Introduce manual activities as method of } \\
\text { relaxation. Refer to session 4 }\end{array}$ & $\begin{array}{c}\text { Discuss with patient their prior } \\
\text { experiences }\end{array}$ \\
\hline $15^{\circ}-65^{\circ}$ & $\begin{array}{r}\text { Stimulate work on creative activities, } \\
\text { painting, nitting, handycraft, etc., }\end{array}$ & $\begin{array}{c}\text { Materials for craft activitiy, } \\
\text { RADL list of participant }\end{array}$ & $\begin{array}{c}\text { Encourage patients to engage in an } \\
\text { interesting activity, give help if needed, } \\
\text { encourage interaction between patients }\end{array}$ \\
\hline $65^{\circ}-80^{\circ}$ & $\begin{array}{r}\text { Exchange about relaxation by activity } \\
\text { aspects }\end{array}$ \\
\hline $80^{\prime}-90^{\prime}$ & $\begin{array}{c}\text { Summary of session and explanation of } \\
\text { treatment topic: .Here you can learn to } \\
\text { take care of yourself when stressed”. } \\
\text { Termination of session }\end{array}$ & List of participants & Free discussion a focummary. \\
\hline
\end{tabular}

11th Session

First impression

\section{Motto of the day: „First impression formation“}

\begin{tabular}{|c|l|}
\hline$\square$ & Your outer appearances decides about how others see you \\
\hline$\square$ & Look the way you want to be seen \\
\hline$\square$ & If one feels bad, one should at least not look bad \\
\hline$\square$ & If the world is grey, put glitter on it \\
\hline$\square$ & \\
\hline
\end{tabular}

In these situations I would like to look attractive:

\begin{tabular}{|c|c|c|c|}
\hline Time (Min) & Contents & Materials & Tasks of Therapist \\
\hline $0^{\prime}-5^{\prime}$ & $\begin{array}{c}\text { Welcoming of participants, } \\
\text { Reiterate motto of the day }\end{array}$ & List of participants, & $\begin{array}{c}\text { Check the list of participants, welcome } \\
\text { new participants }\end{array}$ \\
\hline $5^{\prime}-20^{\prime}$ & $\begin{array}{c}\text { Introduction to the concept of first } \\
\text { impression formation, give example of } \\
\text { prominent persons }\end{array}$ & $\begin{array}{c}\text { MED (minimal emotional } \\
\text { dysfunction) rating form }\end{array}$ & Give information about first impression \\
\hline $20^{\circ}-40^{\circ}$ & $\begin{array}{c}\text { MED (minimal emotional dysfunction) self } \\
\text { rating and observer rating, comparison of } \\
\text { both ratings, focus on clothing }\end{array}$ & MED rating form, pencil & $\begin{array}{c}\text { Be careful and helpful, point to positive } \\
\text { aspects of positive and negative ratings }\end{array}$ \\
\hline $40^{\prime}-80^{\circ}$ & $\begin{array}{c}\text { Set up small groups, participants should } \\
\text { provide and receive individual feedback, } \\
\text { suggestions for improvement }\end{array}$ & MED rating form, digital \\
camera & $\begin{array}{c}\text { Point to aspects which can be } \\
\text { improved, specify what can be changed }\end{array}$ \\
\hline $0^{\prime}-90^{\prime}$ & $\begin{array}{c}\text { Summary of session and explanation of } \\
\text { treatment topic: .Here you can learn to } \\
\text { take care of yourself when stressed”. } \\
\text { Termination of session }\end{array}$ & List of participants & Give a summary. \\
\hline
\end{tabular}


12th Session

First impression

\begin{tabular}{|c|c|c|c|}
\hline Time (Min) & Contents & Materials & Tasks of Therapist \\
\hline $0-5^{\prime}$ & $\begin{array}{l}\text { Welcoming of participants, } \\
\text { Reiterate motto of the day }\end{array}$ & List of participants, & $\begin{array}{c}\text { Check the list of participants, } \\
\text { welcome new participants }\end{array}$ \\
\hline $5^{\prime}-20^{\prime}$ & $\begin{array}{l}\text { Information about importance of body care and } \\
\text { hairstyle, refer to prominent persons }\end{array}$ & $\begin{array}{l}\text { Pictures of prominent } \\
\text { persons, ideally with different } \\
\text { hair styles }\end{array}$ & $\begin{array}{l}\text { Give information about first } \\
\text { impression }\end{array}$ \\
\hline $20^{\prime}-80^{\prime}$ & $\begin{array}{c}\text { All participants should get individual feedback on } \\
\text { their hairstyle and suggestions for improvement, } \\
\text { everybody should try something new (hairstyle, } \\
\text { cosmetics) }\end{array}$ & $\begin{array}{l}\text { MED rating, cosmetic } \\
\text { preparations for hair and } \\
\text { body, digital camera }\end{array}$ & $\begin{array}{l}\text { encourage change and } \\
\text { experiments with hair and } \\
\text { cosmetics }\end{array}$ \\
\hline $80^{\prime}-90^{\prime}$ & $\begin{array}{c}\text { Summary of session and explanation of } \\
\text { treatment topic: „.Here you can learn to take } \\
\text { care of yourself when stressed”. Termination of } \\
\text { session }\end{array}$ & List of participants & Give a summary. \\
\hline
\end{tabular}

13th Session

First impression

\begin{tabular}{|c|c|c|c|}
\hline Time (Min) & Contents & Materials & Tasks of Therapist \\
\hline $0-5^{\prime}$ & $\begin{array}{c}\text { Welcoming of participants, } \\
\text { Reiterate motto of the day }\end{array}$ & $\begin{array}{c}\text { List of participants, } \\
\text { Check the list of participants, } \\
\text { welcome new participants }\end{array}$ \\
\hline $5^{\prime}-20^{\prime}$ & $\begin{array}{c}\text { Information about importance of first impression } \\
\text { formation in different situations, l.,How do I have } \\
\text { to look, if..“, .,.Shall I go to a first date like this“?) }\end{array}$ & $\begin{array}{c}\text { Fill-in MED questionnaire, in } \\
\text { regard to prominent persons }\end{array}$ & $\begin{array}{c}\text { Encourage discussion of partici- } \\
\text { pants }\end{array}$ \\
\hline $20^{\prime}-80^{\prime}$ & $\begin{array}{c}\text { Individual transfer: what are important situations } \\
\text { in my life?, When and where should I change my } \\
\text { attire and outlook? } \\
\text { Set up small groups to give feedback per person }\end{array}$ & $\begin{array}{c}\text { Focus on goals in different situa- } \\
\text { tions; what do I want to achieve }\end{array}$ \\
\hline $80^{\prime}-90^{\prime}$ & $\begin{array}{c}\text { Summary of session and explanation of treat- } \\
\text { ment topic: ,.Here you can learn to take care of } \\
\text { yourself when stressed”. Termination of session }\end{array}$ & List of participants & Give a summary. \\
\hline
\end{tabular}

14th Session

Interaction and smalltalk

Motto of the day: “Interaction and Smalltalk“

\begin{tabular}{|c|l|}
\hline$\square$ & Two heads know more than one. \\
\hline$\square$ & If you start a long journey, take a friend along \\
\hline$\square$ & A problem shared is a problem halved. \\
\hline$\square$ & We all need friends and company \\
\hline$\square$ & \\
\hline
\end{tabular}

Interaction with other people is very important for me in these areas of life: 


\begin{tabular}{|c|c|c|c|}
\hline Time (Min) & Contents & Materials & Tasks of Therapist \\
\hline $0-5^{\prime}$ & $\begin{array}{c}\text { Welcoming of participants, } \\
\text { Reiterate motto of the day }\end{array}$ & $\begin{array}{c}\text { Lheck the list of participants, } \\
\text { welcome new participants }\end{array}$ \\
\hline $5^{\prime}-20^{\prime}$ & $\begin{array}{r}\text { Introduction of the topic social interaction as } \\
\text { method to reduce stress }\end{array}$ & $\begin{array}{c}\text { Give information and encourage } \\
\text { discussion }\end{array}$ \\
\hline $20^{\circ}-80^{\circ}$ & Play parlour games and encourage small talk & Different parlour games & $\begin{array}{c}\text { Encourage participants to engage } \\
\text { ion small talk }\end{array}$ \\
\hline $80^{\prime}-90^{\prime}$ & $\begin{array}{c}\text { Summary of session and explanation of } \\
\text { treatment topic: .,Here you can learn to take } \\
\text { care of yourself when stressed”. Termination } \\
\text { of session }\end{array}$ & List of participants & Give a summary. \\
\hline
\end{tabular}

15th Session

Interaction and smalltalk

\begin{tabular}{|c|c|c|c|}
\hline Time (Min) & Contents & Materials & Tasks of Therapist \\
\hline $0-5^{\prime}$ & $\begin{array}{l}\text { Welcoming of participants, } \\
\text { Reiterate motto of the day }\end{array}$ & List of participants, & $\begin{array}{c}\text { Check the list of participants, welcome } \\
\text { new participants }\end{array}$ \\
\hline $5^{\prime}-20^{\prime}$ & $\begin{array}{c}\text { Repeat experience of last session, } \\
\text { What is difficult, what easy in regard to } \\
\text { small talk }\end{array}$ & & \\
\hline $20^{\circ}-60^{\circ}$ & $\begin{array}{l}\text { Play parlour games and encourage } \\
\text { mutual supportive communication }\end{array}$ & Different parlour games & $\begin{array}{c}\text { Encourage participants to encourage, } \\
\text { console and support each other, especially } \\
\text { when somebody is loosing or making } \\
\text { mistakes }\end{array}$ \\
\hline $60^{\circ}-80^{\circ}$ & $\begin{array}{l}\text { Feedback on experience with } \\
\text { communication }\end{array}$ & & $\begin{array}{l}\text { Encourage discussion, focus on positive } \\
\text { aspects }\end{array}$ \\
\hline $80^{\prime}-90^{\prime}$ & $\begin{array}{c}\text { Summary of session and explanation of } \\
\text { treatment topic: „Here you can learn to } \\
\text { take care of yourself when stressed”. } \\
\text { Termination of session }\end{array}$ & List of participants & Give a summary. \\
\hline
\end{tabular}

\section{REFERENCES}

Hüttner, S-M., Linden, M. (2017). Modification of first impression and interpersonal attractiveness by manipulating outer appearance. Psychopathology, 50, 141-145.

Linden, M., Gehrke, G., Geiselmann, B. (2009). Profiles of recreational activities of daily living (RADL) in patients with mental Disorders. Psychiatria Danubina, 21, 490-496.

Linden M, Weig W, Hrsg. (2009) Salutotherapie. Köln: Deutscher Ärzteverlag

Linden, M., Dymke, T., Hüttner, S.M., Schnaubelt, S. (2016). Der „allgemeine Eindruck (Impression Formation)“ in der Diagnostik und Therapie psychischer Störungen. Psychotherapie, Psychosomatik, medizinische Psychotherapie, 66, 221-226.
Lutz R. (2011) Euthyme Therapie. In: Frank R, Hrsg. Therapieziel Wohlbefinden: Ressourcen aktivieren in der Psychotherapie. Heidelberg: Springer

Otto, J., Linden, M. (2017) Regeneration orientation is better than resistance orientation in behaviour activation. Results from an intervention study with psychosomatic patients. Psychiatria Danubina, 29, 201-206 
Treatment Manual

"Resistance Training"

1st Session

Basic module

\begin{tabular}{|c|c|c|c|}
\hline Time (Min) & Content & Material & Tasks of Therapist \\
\hline $0-5^{\prime}$ & Welcoming of participants & List of participants, & $\begin{array}{l}\text { Check the list of participants, } \\
\text { welcome new participants }\end{array}$ \\
\hline $5^{\prime}-25^{\prime}$ & $\begin{array}{l}\text { Introduction to the concept of minimal cere- } \\
\text { bral dysfunctions (MCD) and skills needed to } \\
\text { cope with stress }\end{array}$ & $\begin{array}{c}\text { Pictures and illustrative ma- } \\
\text { terial }\end{array}$ & $\begin{array}{l}\text { education about the MCD concept } \\
\text { and stress coping skills }\end{array}$ \\
\hline $25^{\prime}-40^{\circ}$ & Completion of the MCD-scale & MCD scale & $\begin{array}{l}\text { Support participants to fill in the } \\
\text { questionnaire }\end{array}$ \\
\hline $40^{\prime}-75^{\prime}$ & $\begin{array}{l}\text { Group discussion on „,compensation strate- } \\
\text { gies“ for personal problems }\end{array}$ & Marker pen and flipchart & $\begin{array}{c}\text { Collect ideas of participants, add } \\
\text { your own suggestions }\end{array}$ \\
\hline $75^{\prime}-80^{\prime}$ & $\begin{array}{c}\text { Listing of individual goals } \mathrm{Q} \text {.,This is what I } \\
\text { want to practice“ }\end{array}$ & $\begin{array}{l}\text { Small index cards for each } \\
\text { patient }\end{array}$ & $\begin{array}{l}\text { Help participants to specify their } \\
\text { training goals }\end{array}$ \\
\hline $80^{\prime}-90^{\prime}$ & $\begin{array}{l}\text { Summary of session and explanation of treat- } \\
\text { ment topic: „Here you can learn step by step } \\
\text { to improve your coping skills with stress” } \\
\text { Termination of session }\end{array}$ & List of participants & Give a summary. \\
\hline
\end{tabular}

2nd Session

Frustration tolerance

Motto of the day: „Frustration tolerance“

\begin{tabular}{|c|l|}
\hline$\square$ & $\begin{array}{l}\text { When it matters, I do not let myself be impressed by ad- } \\
\text { verse conditions. }\end{array}$ \\
\hline$\square$ & The ascent is especially worth it, if it takes a rocky way. \\
\hline$\square$ & Life's not a bowl of cherries. \\
\hline$\square$ & One has to accept the reality: eaten bread is soon forgotten \\
\hline$\square$ & \\
\hline
\end{tabular}

In these areas of life, I need more frustration tolerance:

\begin{tabular}{|c|c|c|c|}
\hline Time (Min) & Content & Material & Tasks of Therapist \\
\hline $0-5^{\prime}$ & Welcoming of participants & List of participants, & $\begin{array}{l}\text { Check the list of participants, } \\
\text { welcome new participants }\end{array}$ \\
\hline $5^{\prime}-10^{\prime}$ & $\begin{array}{l}\text { Introduction in the topic .,frustration } \\
\text { tolerance“, ask for individual mottos }\end{array}$ & $\begin{array}{l}\text { Worksheet for each participant, } \\
\text { pencils }\end{array}$ & $\begin{array}{l}\text { Provide assistance if participants } \\
\text { do not understand the task, discuss } \\
\text { the topic in reference to different } \\
\text { areas in life }\end{array}$ \\
\hline $10^{\prime}-15^{\prime}$ & $\begin{array}{l}\text { Introduction of „Origami“, } \\
\text { „What does frustration tolerance have to } \\
\text { do with it?“ }\end{array}$ & Origami + template & Clarify transfer to life burdens \\
\hline $15^{\prime}-70^{\prime}$ & $\begin{array}{l}\text { Explanation and implementation of } \\
\text { technique by therapists, } \\
\text { Tutorial to fold a figure/ template }\end{array}$ & $\begin{array}{l}\text { Template for each patient, } \\
\text { Origami-Paper }\end{array}$ & $\begin{array}{l}\text { Explain the, motivate the patient } \\
\text { to go on }\end{array}$ \\
\hline $70^{\prime}-80^{\prime}$ & $\begin{array}{l}\text { Feedback: „What have I learned or } \\
\text { practiced regarding my frustration } \\
\text { tolerance” or stress coping skills? }\end{array}$ & $\begin{array}{c}\text { Worksheet for personal } \\
\text { selection-optimization- } \\
\text { compensation (SOC) strategies }\end{array}$ & $\begin{array}{l}\text { Each participant should have the } \\
\text { opportunity to participate in the } \\
\text { discussion }\end{array}$ \\
\hline $80^{\prime}-90^{\prime}$ & $\begin{array}{l}\text { Summary of session and explanation of } \\
\text { treatment topic: „Here you can learn step } \\
\text { by step to improve your coping skills with } \\
\text { stress” Termination of session }\end{array}$ & List of participants & Give a summary. \\
\hline
\end{tabular}


3rd Session

Frustration tolerance

\begin{tabular}{|c|c|c|c|}
\hline Time (Min) & Content & Material & Tasks of Therapist \\
\hline $0-5^{\prime}$ & Welcoming of participants & List of participants, & $\begin{array}{l}\text { Check the list of participants, } \\
\text { welcome new participants }\end{array}$ \\
\hline $5^{\prime}-15^{\prime}$ & $\begin{array}{l}\text { Presentation of the task (.,today we are } \\
\text { going to fold a more difficult figure than } \\
\text { last time“) }\end{array}$ & $\begin{array}{l}\text { Written instruction, Origami } \\
\text { paper for each participant, } \\
\text { individual motto on the topic of } \\
\text { „frustration tolerance" }\end{array}$ & Explain the exercise \\
\hline $15^{\prime}-80^{\circ}$ & Give a time frame & $\begin{array}{l}\text { MCD-sheet to remind the } \\
\text { patient of stress coping skills to } \\
\text { be learned; } \\
\text { Origami materials }\end{array}$ & $\begin{array}{l}\text { Make patients fold origamis, } \\
\text { Support the patient to go on; } \\
\text { discuss the topic in reference to } \\
\text { different areas in life }\end{array}$ \\
\hline $80^{\prime}-90^{\prime}$ & $\begin{array}{c}\text { Summary of session and explanation of } \\
\text { treatment topic: „Here you can learn step } \\
\text { by step to improve your coping skills with } \\
\text { stress” } \\
\text { Termination of session }\end{array}$ & List of participants & Give a summary. \\
\hline
\end{tabular}

\section{4rd Session}

Frustration tolerance

\begin{tabular}{|c|c|c|c|}
\hline Time (Min) & Content & Material & Tasks of Therapist \\
\hline $0-5^{\prime}$ & Welcoming of participants & List of participants, & $\begin{array}{l}\text { Check the list of participants, } \\
\text { welcome new participants }\end{array}$ \\
\hline $5^{\prime}-15^{\prime}$ & $\begin{array}{l}\text { Presentation of the task (.,today we are } \\
\text { going to fold a real difficult figure “) }\end{array}$ & $\begin{array}{l}\text { Written instruction, Origami } \\
\text { paper for each participant, } \\
\text { individual motto on the topic of } \\
\text { „frustration tolerance" }\end{array}$ & Explain the exercise \\
\hline $15^{\prime}-80^{\prime}$ & Give a demanding time frame & $\begin{array}{l}\text { MCD-sheet to remind the } \\
\text { patient of stress coping skills to } \\
\text { be learned; } \\
\text { Origami materials }\end{array}$ & $\begin{array}{l}\text { Make patients fold origamis, } \\
\text { Support the patient to go on; } \\
\text { discuss the topic in reference to } \\
\text { different areas in life }\end{array}$ \\
\hline $80^{\prime}-90^{\prime}$ & $\begin{array}{c}\text { Summary of session and explanation of } \\
\text { treatment topic: „Here you can learn step } \\
\text { by step to improve your coping skills with } \\
\text { stress” } \\
\text { Termination of session }\end{array}$ & List of participants & Give a summary. \\
\hline
\end{tabular}

5th Session

Endurance

Motto of the day: „Endurance “

\begin{tabular}{|c|l|}
\hline$\square$ & Never throw in the towel too early. \\
\hline$\square$ & Only those who keep a stiff upper lip will succeed \\
\hline$\square$ & Giving in is not an option. \\
\hline$\square$ & If something is difficult, just try harder. \\
\hline & If you want to play the piano, you have to practice. \\
\hline & Rome was not build in a day \\
\hline$\square$ & \\
\hline
\end{tabular}

In these areas of life, I need more endurance: 


\begin{tabular}{|c|c|c|c|}
\hline Time (Min) & Content & Material & Tasks of Therapist \\
\hline $0-5^{\prime}$ & Welcoming of participants & List of participants, & $\begin{array}{l}\text { Check the list of participants, } \\
\text { welcome new participants }\end{array}$ \\
\hline $5^{\prime}-15^{\prime}$ & $\begin{array}{l}\text { Introduction into the topic endurance, } \\
\text { presentation of the material .,soap } \\
\text { stone“, exchange of experiences of } \\
\text { patients, link to general framework of } \\
\text { session, }\end{array}$ & $\begin{array}{l}\text { Sheet for individual motto on the } \\
\text { topic of .,endurance“, pencils }\end{array}$ & $\begin{array}{c}\text { Explain the exercise and prepare the } \\
\text { transfer into real life }\end{array}$ \\
\hline $15^{\prime}-80^{\circ}$ & $\begin{array}{l}\text { Set a time frame for making a simple } \\
\text { soap stone figure }\end{array}$ & $\begin{array}{l}\text { Template with pictures of } \\
\text { stone figures, soap stone, MCD } \\
\text { sheet to remind patient of his } \\
\text { personal goals }\end{array}$ & $\begin{array}{l}\text { Support the patient to go on; discuss } \\
\text { the topic in reference to different } \\
\text { areas in life }\end{array}$ \\
\hline $80^{\prime}-90^{\prime}$ & $\begin{array}{c}\text { Summary of session and explanation of } \\
\text { treatment topic: „Here you can learn step } \\
\text { by step to improve your coping skills with } \\
\text { stress” } \\
\text { Termination of session }\end{array}$ & List of participants & Give a summary. \\
\hline
\end{tabular}

\section{6th Session}

\section{Endurance}

\begin{tabular}{|c|c|c|c|}
\hline Time (Min) & Content & Material & Tasks of Therapist \\
\hline $0-5^{\prime}$ & Welcoming of participants & List of participants, & $\begin{array}{l}\text { Check the list of participants, wel- } \\
\text { come new participants }\end{array}$ \\
\hline $5^{\prime}-15^{\prime}$ & $\begin{array}{l}\text { Repetition of the experiences of the last } \\
\text { session, link to general framework of ses- } \\
\text { sion (topic:.,endurance “) and repetition of } \\
\text { individual mottos }\end{array}$ & $\begin{array}{l}\text { Individual materials on the topic } \\
\text { of ..endurance“ }\end{array}$ & Prepare transfer into real life \\
\hline $15^{\prime}-80^{\circ}$ & $\begin{array}{l}\text { Set a time frame for making a moderately } \\
\text { severe soap stone figure }\end{array}$ & $\begin{array}{l}\text { Template with pictures, soap } \\
\text { stone, MCD work sheet }\end{array}$ & $\begin{array}{c}\text { Support the patient to go on; discuss } \\
\text { the topic in reference to different } \\
\text { areas in life }\end{array}$ \\
\hline $80^{\prime}-90^{\prime}$ & $\begin{array}{c}\text { Summary of session and explanation of } \\
\text { treatment topic: „Here you can learn step } \\
\text { by step to improve your coping skills with } \\
\text { stress” } \\
\text { Termination of session }\end{array}$ & List of participants & Give a summary. \\
\hline
\end{tabular}

\section{7th Session}

\section{Endurance}

\begin{tabular}{|c|c|c|c|}
\hline Time (Min) & Content & Material & Tasks of Therapist \\
\hline $0-5^{\prime}$ & Welcoming of participants & List of participants, & $\begin{array}{l}\text { Check the list of participants, } \\
\text { welcome new participants }\end{array}$ \\
\hline $5^{\prime}-15^{\prime}$ & $\begin{array}{l}\text { Repetition of the experiences of the last } \\
\text { session, link to general framework of session } \\
\text { (topic:., endurance “), remind of individual } \\
\text { mottos }\end{array}$ & $\begin{array}{l}\text { Individual materials on the } \\
\text { topic of „endurance“ }\end{array}$ & Prepare transfer into real life \\
\hline $15^{\prime}-80^{\circ}$ & $\begin{array}{l}\text { Set time frame to work on a severe soap stone } \\
\text { figure, give on written instructions (building on } \\
\text { past experiences) }\end{array}$ & $\begin{array}{l}\text { Template with pictures, soap } \\
\text { stone, MCD work sheet }\end{array}$ & $\begin{array}{l}\text { Support the patient to go on; } \\
\text { discuss the topic in reference to } \\
\text { different areas in life }\end{array}$ \\
\hline $80^{\prime}-90^{\prime}$ & $\begin{array}{c}\text { Summary of session and explanation of } \\
\text { treatment topic: „Here you can learn step by } \\
\text { step to improve your coping skills with stress” } \\
\text { Termination of session }\end{array}$ & List of participants & Give a summary. \\
\hline
\end{tabular}


8th Session

Accuracy

My motto of the day: „Accuracy“

\begin{tabular}{|c|l|}
\hline$\square$ & If you do the work properly from the beginning, you save time. \\
\hline$\square$ & Doing something correctly is better than doing it sloppy. \\
\hline$\square$ & Sloppiness is not a virtue. \\
\hline$\square$ & \\
\hline$\square$ & \\
\hline Here I have to be especially tolerant towards grievance:
\end{tabular}

...and here I am confronted with undesired responsibilities

\begin{tabular}{|c|c|c|c|}
\hline Time (Min) & Content & Material & Tasks of Therapist \\
\hline $0-5^{\prime}$ & Welcoming of participants & List of participants, & $\begin{array}{l}\text { Check the list of participants, } \\
\text { welcome new participants }\end{array}$ \\
\hline $5^{\prime}-15^{\prime}$ & $\begin{array}{l}\text { Introduction into the topic accuracy, } \\
\text { presentation of silhouette cutting, exchange } \\
\text { of experiences of patients, link to general } \\
\text { framework of session, }\end{array}$ & $\begin{array}{l}\text { Sheet for individual motto on } \\
\text { the topic of .,accuracy“, pencils }\end{array}$ & $\begin{array}{l}\text { Explain the exercise and } \\
\text { prepare the transfer into real } \\
\text { life }\end{array}$ \\
\hline $15^{\prime}-30^{\circ}$ & $\begin{array}{l}\text { Set a time frame for making a first silhouette, } \\
\text { Explain the need of concentration and accuracy }\end{array}$ & Examples, scissors, paper & $\begin{array}{l}\text { Support the patient to go on; } \\
\text { discuss the topic in reference to } \\
\text { different areas in life }\end{array}$ \\
\hline $30-40$ & Summary, what was easy, what diffficult & & Get response from patients \\
\hline $40-75$ & Make another silhouette & Paper, scissors, template & $\begin{array}{l}\text { Support the patient to go on; } \\
\text { discuss the topic in reference to } \\
\text { different areas in life }\end{array}$ \\
\hline $75-80$ & Presentatin of results in the group & & $\begin{array}{l}\text { Focus on strategies to reach } \\
\text { accuracy, irrespective of results }\end{array}$ \\
\hline $80^{\prime}-90^{\prime}$ & $\begin{array}{c}\text { Summary of session and explanation of } \\
\text { treatment topic: „Here you can learn step by } \\
\text { step to improve your coping skills with stress” } \\
\text { Termination of session }\end{array}$ & List of participants & Give a summary. \\
\hline
\end{tabular}

\section{9th Session}

\section{Accuracy}

\begin{tabular}{|c|c|c|c|}
\hline Time (Min) & Content & Material & Tasks of Therapist \\
\hline $0-5^{\prime}$ & Welcoming of participants & MCD sheet & $\begin{array}{c}\text { Check the list of participants, } \\
\text { welcome new participants }\end{array}$ \\
\hline $5^{\prime}-15^{\prime}$ & $\begin{array}{r}\text { Repetition of past lessons, what has been } \\
\text { learned }\end{array}$ & Collect group responses \\
\hline $15^{\prime}-25^{\circ}$ & Instruction to weaving of a wicket basket & $\begin{array}{c}\text { Materials for basket weaving for } \\
\text { each patient }\end{array}$ & $\begin{array}{c}\text { Pay attention to time, encourage } \\
\text { participants to go on }\end{array}$ \\
\hline $25^{\prime}-80^{\prime}$ & $\begin{array}{r}\text { Basket weaving and focusing on personal } \\
\text { problems in reference to MCD sheet }\end{array}$ & Specify compensatory strategies \\
\hline $80^{\prime}-90^{\prime}$ & $\begin{array}{c}\text { Summary of session and explanation of } \\
\text { treatment topic: .Here you can learn step by } \\
\text { step to improve your coping skills with stress” } \\
\text { Termination of session }\end{array}$ & List of participants & Give a summary. \\
\hline
\end{tabular}


10th Session

Accuracy

\begin{tabular}{|c|c|c|c|}
\hline Time (Min) & Content & Material & Tasks of Therapist \\
\hline $0-5^{\prime}$ & Welcoming of participants & List of participants, & $\begin{array}{c}\text { Check the list of participants, } \\
\text { welcome new participants }\end{array}$ \\
\hline $5^{\prime}-15^{\prime}$ & Repetition of what has been learned & MCD worksheet & Summarize results \\
\hline $15^{\prime}-80^{\prime}$ & $\begin{array}{c}\text { Continuation of basket weaving, focus on } \\
\text { difficulties and compensatory strategies }\end{array}$ & $\begin{array}{c}\text { Materials for basket weaving for } \\
\text { each patient }\end{array}$ & $\begin{array}{c}\text { strategies, support transfer into } \\
\text { real life }\end{array}$ \\
\hline $80^{\prime}-90^{\prime}$ & $\begin{array}{c}\text { Summary of session and explanation of } \\
\text { treatment topic: „Here you can learn step by } \\
\text { step to improve your coping skills with stress” } \\
\text { Termination of session }\end{array}$ & List of participants & Give a summary. \\
\hline
\end{tabular}

11th Session

Goal orientation and acceptance of undesired tasks

Motto of the day: „Goal orientation and acceptance of undesired tasks “

\begin{tabular}{|c|l|}
\hline$\square$ & If you want success, go on even if you feel bad \\
\hline$\square$ & Do not allow distress to distract you from your responsibilities \\
\hline$\square$ & What must be done has to be done \\
\hline$\square$ & If you can not change it, accept it \\
\hline$\square$ & There is no choice, then make the best out of it \\
\hline$\square$ & Business over pleasure. \\
\hline$\square$ & \\
\hline
\end{tabular}

These are task I have to do, although I do not like it:

\begin{tabular}{|c|c|c|c|}
\hline Time (Min) & Content & Material & Tasks of Therapist \\
\hline $0-5^{\prime}$ & Welcoming of participants & List of participants, & $\begin{array}{c}\text { Check the list of } \\
\text { participants, welcome new } \\
\text { participants }\end{array}$ \\
\hline $5^{\prime}-15^{\prime}$ & $\begin{array}{c}\text { Presentation of the motto of today "goal } \\
\text { orientation and acceptance of undesired } \\
\text { tasks" }\end{array}$ & $\begin{array}{l}\text { Personal motto on ." "goal orientation } \\
\text { and acceptance of undesired tasks" }\end{array}$ & $\begin{array}{l}\text { support participants to } \\
\text { find their own motto on } \\
\text { acceptance of undesired } \\
\text { tasks }\end{array}$ \\
\hline $15-30^{\prime}$ & Introduction to wood carving & Illustrative material & $\begin{array}{l}\text { Explain how to work with } \\
\text { wood }\end{array}$ \\
\hline $30^{\prime}-70^{\prime}$ & Work on wood with sandpaper & $\begin{array}{l}\text { Wooden blocks, sandpaper for each } \\
\text { participant }\end{array}$ & $\begin{array}{l}\text { Pay attention to time, } \\
\text { encourage participants to } \\
\text { go on }\end{array}$ \\
\hline $70^{\prime}-80$ & $\begin{array}{l}\text { Presentation of results in the group } \\
\text { by each participant, what were the } \\
\text { difficulties, feedback on performance, } \\
\text { suggestions for improvement }\end{array}$ & MCD sheet & $\begin{array}{l}\text { Ask participants specifically } \\
\text { about compensatory } \\
\text { strategies, reinforce effort } \\
\text { independent of result }\end{array}$ \\
\hline $80^{\prime}-90^{\prime}$ & $\begin{array}{c}\text { Summary of session and explanation of } \\
\text { treatment topic: „Here you can learn step } \\
\text { by step to improve your coping skills with } \\
\text { stress” } \\
\text { Termination of session }\end{array}$ & List of participants & Give a summary. \\
\hline
\end{tabular}


12th Session

Goal orientation and acceptance of undesired tasks

\begin{tabular}{|c|c|c|c|}
\hline Time (Min) & Content & Material & Tasks of Therapist \\
\hline $0-5^{\prime}$ & Welcoming of participants & List of participants, & $\begin{array}{l}\text { Check the list of participants, } \\
\text { welcome new participants }\end{array}$ \\
\hline $5^{\prime}-15^{\prime}$ & $\begin{array}{l}\text { Presentation of the motto of the day: "goal } \\
\text { orientation and acceptance of undesired } \\
\text { tasks", repetition of earlier experiences }\end{array}$ & $\begin{array}{l}\text { Individual motto of the day } \\
\text { regarding "goal orientation and } \\
\text { acceptance of undesired tasks" }\end{array}$ & $\begin{array}{l}\text { Reiterate the results from past } \\
\text { session }\end{array}$ \\
\hline $15^{\prime}-25^{\prime}$ & Work on Rubick cube and brain teaser & Rubick cube for each participant & $\begin{array}{l}\text { Explain the Rubick cube } \\
\text { task, motivate to go on at the } \\
\text { beginning and then step back }\end{array}$ \\
\hline $25^{\prime}-30^{\prime}$ & $\begin{array}{l}\text { Discussion on current task, Where are my own } \\
\text { limits? Collection of ideas on solutions }\end{array}$ & MCD sheet & Specify compensation strategies \\
\hline $30^{\prime}-80^{\prime}$ & $\begin{array}{l}\text { Continue work on complex wood structures } \\
\text { with sandpaper }\end{array}$ & $\begin{array}{l}\text { Wooden blocks. Sandpaper for } \\
\text { each participant }\end{array}$ & $\begin{array}{c}\text { Pay attention to time, encourage } \\
\text { participants to go on }\end{array}$ \\
\hline $80^{\prime}-90^{\prime}$ & $\begin{array}{c}\text { Summary of session and explanation of } \\
\text { treatment topic: „Here you can learn step by } \\
\text { step to improve your coping skills with stress” } \\
\text { Termination of session }\end{array}$ & List of participants & Give a summary. \\
\hline
\end{tabular}

13th Session

Goal orientation and acceptance of undesired tasks

\begin{tabular}{|c|c|c|c|}
\hline Time (Min) & Content & Material & Tasks of Therapist \\
\hline $0-5^{\prime}$ & Welcoming of participants & List of participants, & $\begin{array}{l}\text { Check the list of } \\
\text { participants, welcome new } \\
\text { participants }\end{array}$ \\
\hline $5^{\prime}-15^{\prime}$ & $\begin{array}{c}\text { Presentation of today's contents: } \\
\text { Presentation of the motto of the day "goal } \\
\text { orientation and acceptance of undesired } \\
\text { tasks" }\end{array}$ & $\begin{array}{l}\text { Personal motto on "goal orientation } \\
\text { and acceptance of undesired tasks", }\end{array}$ & $\begin{array}{l}\text { support participants to find } \\
\text { their own motto }\end{array}$ \\
\hline $10^{\prime}-30^{\circ}$ & Moderately severe brain teaser & $\begin{array}{c}\text { Package of brain teasers for each } \\
\text { participant }\end{array}$ & $\begin{array}{l}\text { Pay attention to time, } \\
\text { encourage participants to } \\
\text { gon on }\end{array}$ \\
\hline $30^{\prime}-40^{\prime}$ & $\begin{array}{c}\text { Discussion of task, Where are my own } \\
\text { limits? }\end{array}$ & Motto on flexibility & $\begin{array}{l}\text { Specify compensatory } \\
\text { strategies }\end{array}$ \\
\hline $50^{\prime}-80^{\prime}$ & Work on wood with sandpaper & $\begin{array}{l}\text { Wooden blocks, sandpaper for each } \\
\text { participant }\end{array}$ & $\begin{array}{l}\text { Pay attention to time, } \\
\text { encourage participants to } \\
\text { go on }\end{array}$ \\
\hline $70^{\prime}-80$ & $\begin{array}{c}\text { Presentation of results in the group } \\
\text { by each participant, what were the } \\
\text { difficulties, feedback on performance, } \\
\text { suggestions for improvement }\end{array}$ & MCD sheet & $\begin{array}{l}\text { Ask participants specifically } \\
\text { about compensatory } \\
\text { strategies, reinforce effort } \\
\text { independent of result }\end{array}$ \\
\hline $80^{\prime}-90^{\prime}$ & $\begin{array}{c}\text { Summary of session and explanation of } \\
\text { treatment topic: „. Here you can learn step } \\
\text { by step to improve your coping skills with } \\
\text { stress” } \\
\text { Termination of session }\end{array}$ & List of participants & Give a summary. \\
\hline
\end{tabular}


14th Session

Acceptance of stress and criticism

Motto of the day: „Acceptance of stress and criticism“

\begin{tabular}{|c|l|}
\hline$\square$ & Do not allow everything to touch you. \\
\hline$\square$ & If I am mad on me, it is myself who is mad on me \\
\hline$\square$ & This is life: sometimes you win, sometimes you loose \\
\hline & Take it as it is \\
\hline & Be happy don't worry \\
\hline$\square$ & \\
\hline
\end{tabular}

\begin{tabular}{|c|c|c|c|}
\hline Time (Min) & Content & Material & Tasks of Therapist \\
\hline $0-5^{\prime}$ & Welcoming of participants & List of participants, & $\begin{array}{l}\text { Check the list of participants, } \\
\text { welcome new participants }\end{array}$ \\
\hline $5^{\prime}-15^{\prime}$ & $\begin{array}{l}\text { Repetition of the mottos on the topic of } \\
\text { „Acceptance of stress and criticism “, } \\
\text { preparation of transfer } \square \text { Where could I use it? }\end{array}$ & $\begin{array}{l}\text { individual mottos for each } \\
\text { participant }\end{array}$ & $\begin{array}{l}\text { Compile the results, motivate } \\
\text { participants, refer to individual } \\
\text { mottos }\end{array}$ \\
\hline $15^{\prime}-35^{\circ}$ & $\begin{array}{c}\text { Block of tasks I: Solving of simple brain } \\
\text { teasers under time pressure and competitive } \\
\text { pressure }\end{array}$ & $\begin{array}{l}\text { package with brain teaser for } \\
\text { each participant }\end{array}$ & Pay attention to time regulation \\
\hline $35^{\prime}-45^{\prime}$ & $\begin{array}{c}\text { Evaluation of the first block of tasks, .,What } \\
\text { was easy?“, ..What was difficult?" ,...What was } \\
\text { stressful?", ..Does the stress remind me of } \\
\text { other situations?“ }\end{array}$ & MCD work sheet & $\begin{array}{l}\text { Specify compensatory } \\
\text { strategies, focus on transfer } \\
\text { perspective }\end{array}$ \\
\hline $45^{\prime}-65^{\prime}$ & $\begin{array}{l}\text { Block of tasks II: Solving of difficult brain } \\
\text { teasers under time pressure and competitve } \\
\text { pressure, evaluation of results in the group }\end{array}$ & $\begin{array}{c}\text { package with brain teaser for } \\
\text { each participant }\end{array}$ & $\begin{array}{c}\text { Compile the results, motivate } \\
\text { participants, refer to individual } \\
\text { mottos }\end{array}$ \\
\hline $65^{\prime}-80^{\prime}$ & $\begin{array}{l}\text { Evaluation of the second block of tasks, ..What } \\
\text { was easy?", .,What was difficult?" ,.,What was } \\
\text { stressful?", ., Does the stress remind me of } \\
\text { other situations?", comparison with first task }\end{array}$ & MCD work sheet & $\begin{array}{l}\text { Specify compensatory } \\
\text { strategies, apply topic across } \\
\text { different areas in life }\end{array}$ \\
\hline $80^{\prime}-90^{\prime}$ & $\begin{array}{c}\text { Summary of session and explanation of } \\
\text { treatment topic: „Here you can learn step by } \\
\text { step to improve your coping skills with stress” } \\
\text { Termination of session }\end{array}$ & List of participants & Give a summary. \\
\hline
\end{tabular}

15th Session

Acceptance of stress and criticism

\begin{tabular}{|c|c|c|c|}
\hline Time (Min) & Content & Material & Tasks of Therapist \\
\hline $0-5^{\prime}$ & Welcoming of participants & List of participants, & $\begin{array}{l}\text { Check the list of participants, } \\
\text { welcome new participants }\end{array}$ \\
\hline $5^{\prime}-15^{\prime}$ & $\begin{array}{l}\text { Discussion of the topic „Acceptance of stress } \\
\text { and criticism“ }\end{array}$ & $\begin{array}{l}\text { Personal motto on acceptance of } \\
\text { stress and criticism }\end{array}$ & $\begin{array}{l}\text { Support participants to find } \\
\text { their own specific motto of the } \\
\text { day }\end{array}$ \\
\hline $15^{\prime}-25^{\circ}$ & $\begin{array}{c}\text { Explain „Tangram“, hand out materials, give } \\
\text { an easy task, set out time frame }\end{array}$ & $\begin{array}{l}\text { Tangram-packages for each } \\
\text { participant }\end{array}$ & $\begin{array}{l}\text { Pay attention to time, } \\
\text { encourage participants to go on }\end{array}$ \\
\hline $25^{\prime}-35^{\prime}$ & Second Tangram task, moderately severe task & $\begin{array}{c}\text { Tangram-packages for each } \\
\text { participant }\end{array}$ & $\begin{array}{l}\text { Pay attention to time, } \\
\text { encourage participants to go on }\end{array}$ \\
\hline
\end{tabular}




\begin{tabular}{|c|c|c|c|}
\hline Time (Min) & Content & Material & Tasks of Therapist \\
\hline $35^{\prime}-45^{\prime}$ & $\begin{array}{l}\text { Summary: What was the task, what were the } \\
\text { difficulties, how did you manage to go on? }\end{array}$ & MCD work sheet & $\begin{array}{l}\text { Summarize and transfer ideas } \\
\text { of participants to real life }\end{array}$ \\
\hline $45^{\prime}-65^{\prime}$ & difficult Tanagram task & $\begin{array}{l}\text { Tanagram-packages for each } \\
\text { participant }\end{array}$ & $\begin{array}{l}\text { Pay attention to time, } \\
\text { encourage participants to go on }\end{array}$ \\
\hline $65^{\prime}-80$ & $\begin{array}{l}\text { Summary: What was the task, what were the } \\
\text { difficulties, how did you manage problems? }\end{array}$ & MCD work sheet & $\begin{array}{l}\text { Summarize and transfer ideas } \\
\text { of participants to real life }\end{array}$ \\
\hline $80^{\prime}-90^{\prime}$ & $\begin{array}{c}\text { Summary of session and explanation of } \\
\text { treatment topic: „Here you can learn step by } \\
\text { step to improve your coping skills with stress” } \\
\text { Termination of session }\end{array}$ & List of participants & Give a summary. \\
\hline
\end{tabular}

\section{REFERENCES}

Linden, M., Weddigen, J. (2016). Teilleistungsstörungen/MCD und ADHS im Erwachsenenalter. Der Nervenarzt, 87 (11), 1175-1184.

Otto, J., Linden, M. (2017) Regeneration orientation is better than resistance orientation in behaviour activation. Results from an intervention study with psychosomatic patients. Psychiatria Danubina, 29, (2) 201-206 
